\title{
SHORT-TERM VARIABILITY OF COPEPOD ABUNDANCE IN JURUMIRIM RESERVOIR, SÃO PAULO, BRAZIL
}

\author{
PANARELLI, E. A., NOGUEIRA, M. G. and HENRY, R. \\ Departamento de Zoologia, Instituto de Biociências, Unesp, CEP 18618-000, \\ Rubião Junior, Botucatu, SP, Brazil \\ Correspondence to: Eliana A. Panarelli, Departamento de Zoologia, Instituto de Biociências, Unesp, \\ CEP 18618-000, Rubião Junior, Botucatu, SP, Brazil, e-mail: zoologia@ibb.unesp.br \\ Received July 26, 2000 - Accepted November, 28, 2000 - Distributed November 30, 2001
}

(With 18 figures)

\begin{abstract}
Short-term variability in composition and abundance of copepod populations were studied during the dry (winter) and rainy (summer) seasons, at the dam region of Jurumirim Reservoir, São Paulo, Brazil. An intensive sampling program was carried out during 30 days in each period of the year. Samples and measurements were taken every other day at $0,5,10,15,20$ and $25 \mathrm{~m}$ depths. The relationship between variability of the populations and some environmental factors was analyzed. The main species were: Argyrodiaptomus furcatus (Sars), Notodiaptomus iheringi (Wright), Mesocyclops longisetus (Thiébaud), Thermocyclops decipiens (Fischer), and T. minutus (Lowndes). Thermocyclops minutus was the most abundant species in dry season and its abundance varied significantly between sampling days. A large increase in abundance of calanoids occurred during the rainy season. This increase was correlated with higher temperature values. At that time, Notodiaptomus iheringi was dominant. This species showed significant short-term variations in abundance in both dry and rainy seasons. Significant variation in density of populations within the same sampling period might result from either the dispersion pattern of the populations or continuous substitution of the water masses. Significant correlation was observed between copepod abundance and temperature, especially for species of calanoids and there was also some correlations between densities of particular species of copepods and some phytoplankton taxa, mainly during the dry season. As for vertical distribution, most organisms were found between the surface and $15 \mathrm{~m}$ deep. During the rainy season, there was some evidence of the occurrence of spatial segregation between species of cyclopoids and calanoids, with the cyclopoids in a deeper position within the water column.
\end{abstract}

Key words: short-term variability, copepod, Calanoida, Cyclopoida, tropical reservoir.

\section{RESUMO}

\section{Variabilidade em curto prazo na abundância de copépodos na Represa de Jurumirim, São Paulo, Brasil}

O presente estudo examinou a variabilidade na composição e na abundância das populações de copépodos, em dois períodos do ano, seco (inverno) e chuvoso (verão), na região da barragem da Represa de Jurumirim, São Paulo, Brasil. Foram realizadas coletas a cada 48 horas, durante 30 dias, em cada período; a amostragem da comunidade e as medidas das variáveis ambientais foram feitas a $0,5,10,15,20$ e 25 metros de profundidade. As relações entre a variabilidade das populações e alguns fatores ambientais foram analisadas. As principais espécies encontradas foram: Argyrodiaptomus furcatus (Sars), Notodiaptomus iheringi (Wright), Mesocyclops longisetus (Thiébaud), Thermocyclops decipiens (Fischer) e T. minutus (Lowndes). Thermocyclops minutus foi a espécie mais abundante no período seco e sua densidade variou significativamente entre os dias de amostragem. Ocorreu um grande aumento na abundância de Calanoida durante a estação chuvosa. Esse aumento foi correla- 
cionado a maiores valores de temperatura. Nessa época, Notodiaptomus iheringi foi dominante, a densidade dessa espécie apresentou variações de curto prazo significativas em ambos os períodos de estudo. Variações significativas na densidade das populações dentro de um mesmo período de estudo podem ser resultado do padrão de dispersão das populações ou da substituição contínua das massas de água. Foram observadas correlações significativas entre a abundância de copépodos e a temperatura, especialmente para as espécies de Calanoida; também foram observadas correlações entre algumas espécies de copépodos e alguns táxons fitoplanctônicos, principalmente durante a estação seca. Durante a época chuvosa, notaram-se evidências de segregação espacial entre as espécies de Cyclopoida e Calanoida; os Cyclopoida, algumas vezes, foram encontrados em maior densidade na camada mais profunda da coluna d'água.

Palavras-chave: variabilidade de curto prazo, Copepoda, Calanoida, Cyclopoida, reservatório tropical.

\section{INTRODUCTION}

Population adaptation to the limnetic environment is the result of a complex evolutionary process mediated by interactions between biotic and abiotic factors. Variations in the environment can promote cyclic or erratic changes in the activities of the organisms, short-and long-term fluctuations in the abundance of populations or even substitution of the species. Information on how the structure of a community changes, at different temporal scales, can contribute to a better understanding of the functioning and evolution of the ecosystem.

Several researchers in Brazil have investigated patterns of temporal variations of the zooplankton, including populations of Copepoda. Most of the studies have considered diurnal rhythms and seasonal fluctuations (Tomm et al., 1982; Fisher et al., 1983; Infante, 1982; Matsumura-Tundisi \& Okano, 1983; Matsumura-Tundisi et al., 1989; Lansac-Tôha et al., 1995; Nogueira \& Matsumura-Tundisi, 1996; Nogueira \& Panarelli, 1997). However, information about shortterm fluctuations in density are scarce, despite the fact they can have an important role in plankton dynamics in tropical zones. According to Nilssen (1984), higher velocities of biological processes in the tropics are the main difference between temperate and low latitude lakes. Moreover, reservoirs built for hydroelectric production tend to show lower hydrodynamics stability, due to the shorter water retention time, than natural lakes. Thus, studies on short-term variability are of major importance for understanding the dynamics plankton communities in this kind of ecosystem, which can be subject not only to the natural variations but also to variations imposed by the operational system for electricity production.

The aim of this study is to investigate patterns in short-term variability of zooplancton abundance in the lacustrine zone of a tropical reservoir (Jurumirim Reservoir), located in the State of São Paulo, Brazil. Sampling was carried out in the dry (winter) and rainy (summer) seasons in order to discriminate the influence of seasonal effects. In this paper we present data on Copepoda populations while data on Cladocera and Rotifera are being analyzed to be published opportunely.

\section{STUDY AREA}

Jurumirim Reservoir (Fig. 1) is a large reservoir built in 1962 for generating hydroelectricity. It is located in the upper region of the Paranapanema River (Upper Paraná basin), State of São Paulo, Brazil. The main water body is positioned between latitudes $23^{\circ} 08^{\prime}$ ' and $23^{\circ} 35^{\prime}$ 'S and longitudes $48^{\circ} 30^{\prime}$ and $49^{\circ} 13^{\prime} \mathrm{W}$. The reservoir receives two large tributaries on its southern side, the Paranapanema and Taquari rivers, and several small rivers and streams enter the northern shore.

The zone of the reservoir near the dam is oligotrophic with characteristics of a warm monomictic system. Thermal stratification is observed during the rainy season and a mixing period occurs during the dry season. Further information on primary production, as well as physical and chemical characteristics of this reservoir, including its different spatial compartiments can be found in Henry (1990, 1992, 1993a, 1993b); Henry \& Gouveia (1993); Henry \& Maricatto (1996); Henry \& Nogueira (1999); Nogueira et al. (1999). 


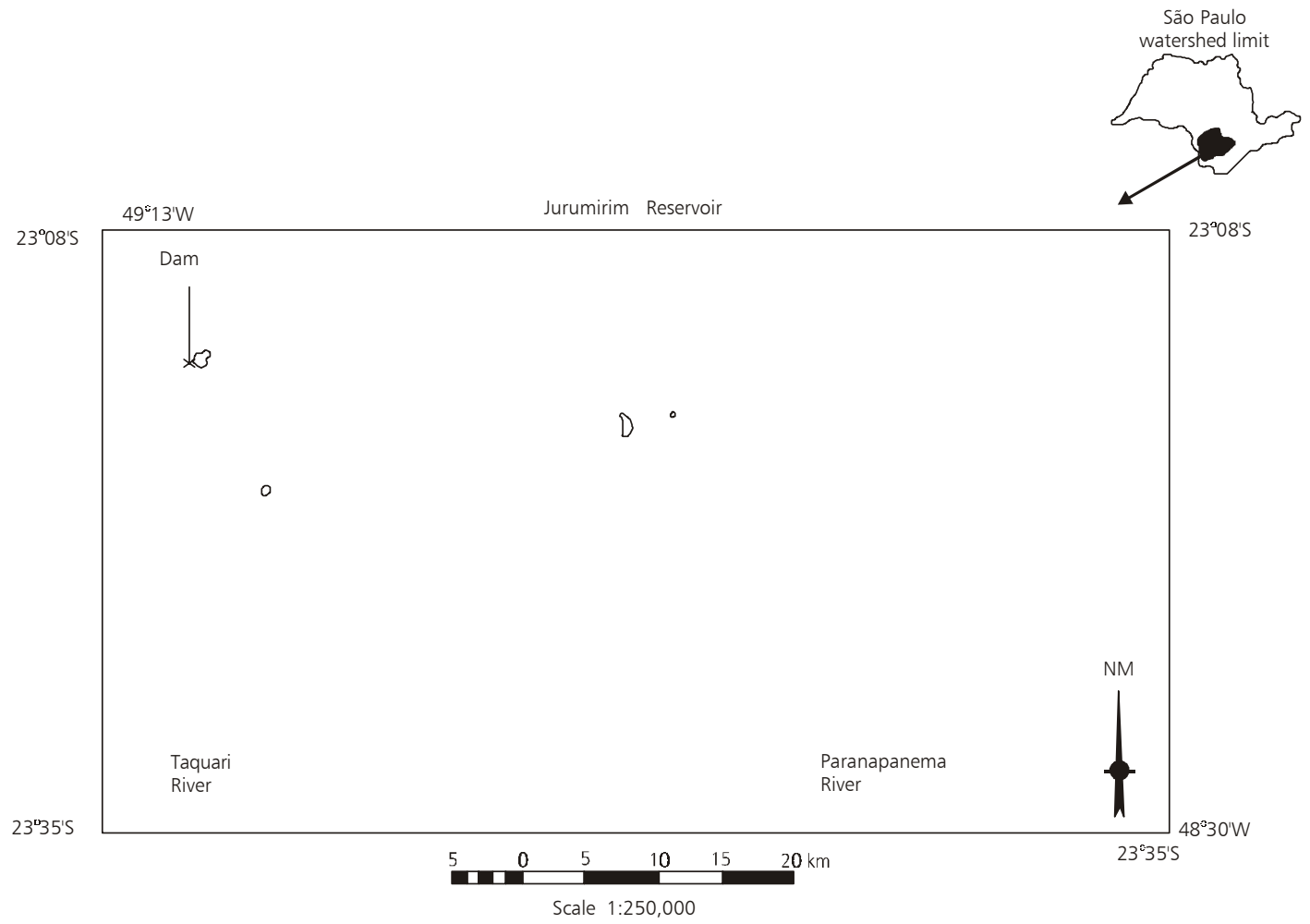

Fig. 1 - Location of Jurumirim Reservoir and position of the sampling station (Dam).

Some morphometric characteristics, including outflow during the sampling periods, are shown in Table 1.

\section{MATERIAL AND METHODS}

The data were obtained in the lacustrine zone of the Jurumirim Reservoir (Paranapanema River, State of São Paulo), at a sampling station located $3 \mathrm{~km}$ from the dam. Local depth was $30 \mathrm{~m}$. Physical and chemical measurements and zooplankton samples were taken every 5 meters from the surface to $25 \mathrm{~m}$. Field work was carried out every other day (in the morning) from 1 to 29 July 1993 (dry season winter) and from 11 January to 8 February 1994 (rainy season summer).

Water transparency was measured with a Secchi disk; water temperature with a Toho Dentan thermistor (ET-3); dissolved oxygen by the Winkler method (Golterman et al., 1978); $\mathrm{pH}$ with a Micronal B380 pHmeter; conductivity with a Hatch conductivimeter (model 2511); suspended solids by gravimetry, as described in Cole (1979), and the phytoplankton biomass (chlorophyll-a concentration) was estimated according to Golterman et al. (1978), using cold acetone as solvent. Climatological data (air temperature, wind speed and precipitation) acquired from a meteorological station located near the dam were supplied by the electric company, Cesp (Companhia Energética de São Paulo).

For quantitative analysis of the zooplankton, 300 liters of water were collected at each sampling layer using a gasoline pumping system connected to a hose $38 \mathrm{~mm}$ in diameter. This volume was filtered using a plankton net of $55 \mu \mathrm{m}$ mesh size. A net with the same mesh size was used in vertical hauls for taking samples for qualitative analysis. All samples were preserved in $4 \%$ formalin. Papers of MatsumuraTundisi (1986); Reid (1985, 1988, 1989); Rocha \& Matsumura-Tundisi (1976); Sendacz \& Kubo (1982) were used for fying species. 
TABLE 1

Morphometric characteristics of Jurumirim Reservoir.

\begin{tabular}{|l|l|}
\hline Area & $446 \mathrm{~km}^{2}$ \\
\hline Volume & $7.9 \times 10^{9} \mathrm{~m}^{3}$ \\
\hline Retention time (1991-1992) & 334 days \\
\hline Maximum length & $30.75 \mathrm{~km}$ \\
\hline Maximum width & $10.50 \mathrm{~km}$ \\
\hline Mean depth & $12.9 \mathrm{~m}$ \\
\hline Maximum depth & $40.0 \mathrm{~m}$ \\
\hline Shoreline development index & 14.9 \\
\hline Perimeter & $1,115 \mathrm{~km}^{-1}$ \\
\hline Average outflow: 29/June-29/July/1993 (dry season) & $223.81 \mathrm{~m}^{3} . \mathrm{s}^{-1}$ \\
\hline Average outflow: 9/January-8/ February/1994 (rainy season) & $186.00 \mathrm{~m}^{3} . \mathrm{s}^{-1}$ \\
\hline
\end{tabular}

Source: Division of Operation for the Hydroelectric of Jurumirim; modified from Henry (1990) and Nogueira et al. (1999).

Calanoida (nauplii, copepodids and adults) and Cyclopoida (adults and copepodids) were counted on a stereo microscope (ZEISS, Stemi SV6), using sub-samples with at least 150 individuals or the entire sample, when the density of organisms was low. Sub-samples (with at least 150 organisms) were used to count nauplii of Cyclopoida in Sedgwick-Rafter chambers, using an optical microscope (ZEISS, Standard 25). Schematic drawings (camara lucida) and pictures (scanning microscopy) of the species are showed in Figs. 4, $5,6,7$, and 8 .

Statistical analyses were performed to verify short-term variability of copepod abundance (ANOVA), and also to detect correlation between abiotic factors and population densities of copepods and phytoplankton (Pearson correlation). The values of abundance for phytoplankton taxa were obtained from Ferreira (1998), who analyzed the total phytoplankton collected at the same sampling station, in the same depths and on the same days when the zooplankton were sampled. For both analyses SAS software was used.

\section{RESULTS}

\section{Environmental factors}

For some variables, e.g., precipitation, water temperature, dissolved oxygen, and chlorophyll- a the differences between the periods studied were evident.

The data on precipitation and wind speed are represented in Fig. 2. During the sampling period corresponding to the dry season the rainfall was low, $1.13 \%$ of total precipitation for 1993. During the sampling period corresponding to the rainy season, precipitation was relatively high but not frequent and constituted $23.76 \%$ of the total for 1994. Wind speed showed high daily oscillations for both periods of the year. During the rainy season

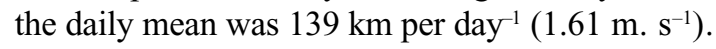
In the dry season there were longer periods of low wind speed and the daily mean was $116 \mathrm{~km}$ per $\operatorname{day}^{-1}\left(1.35 \mathrm{~m} . \mathrm{s}^{-1}\right)$.

Some vertical profiles of water temperature and dissolved oxygen are shown in Fig. 3. In the dry season the water column remained isothermal and the profiles varied between $19^{\circ} \mathrm{C}$ and $21^{\circ} \mathrm{C}$ for most of the period; there were also some nearsurface microstratifications. During the rainy season a thermocline was generally observed below $20 \mathrm{~m}$ and occasionally some secondary stratification occurred in the superficial layers. Temperature ranged between $24^{\circ} \mathrm{C}$ and $27^{\circ} \mathrm{C}$ in the epilimnion and between $21^{\circ} \mathrm{C}$ and $23^{\circ} \mathrm{C}$ in deeper layers. High oxygen concentrations were observed, with a relatively homogeneous vertical distribution during the dry season. 

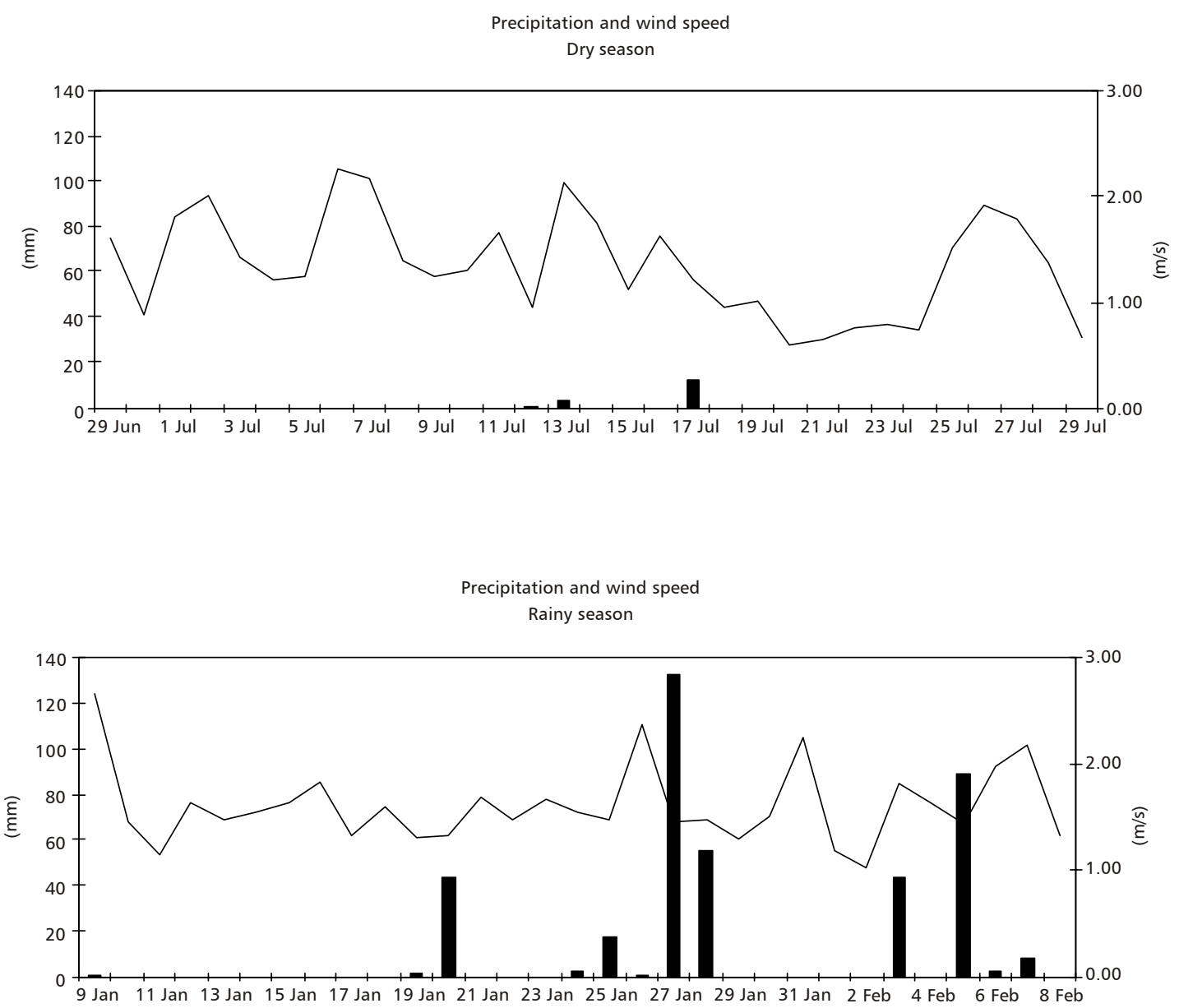

Fig. 2 - Daily precipitation $(\mathrm{mm})$ and wind speed $(\mathrm{m} / \mathrm{s})$ near the dam of Jurumirim Reservoir, during the dry and rainy seasons.

In the rainy season there was a significant oxygen decrease below $20 \mathrm{~m}$ in the meta and hypolimnetic zones.

The chlorophyll-a concentrations (Fig. 9) were higher in the dry season. During this period there was a remarkable daily variation in the values measured in the water column. In the rainy season a relatively low variation in chlorophyll concentration was observed, except for the first ten days.

The results of the variance analysis performed in order to identify differences between sampling days and between depths are shown in Table 2 . There were significant differences, between sampling days for both periods studied. There was no significant variation for vertical distribution of the environmental variables during the dry season. However, most variables showed significant differences in the water column during the rainy season.

\section{Copepoda}

Copepoda is an important group in the zooplankton of Jurumirim Reservoir. They constituted, in terms of mean density, $26 \%$ and $27 \%$ of the total zooplankton (Cladocera 6\% and 9\%; Rotifera 64\% and $63 \%$ ) in the dry and rainy season, respectively (Panarelli, 1999). The abundance of Copepoda varied significantly within the same sampling period, for both dry and rainy seasons. 

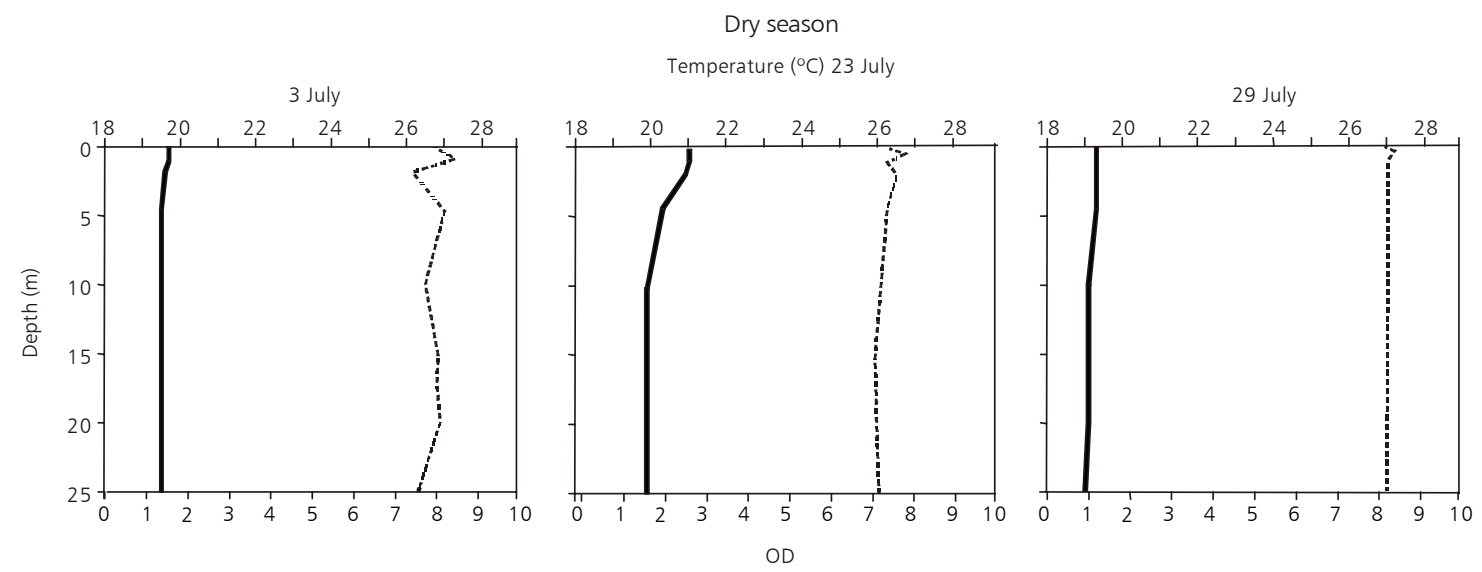

Rainy season
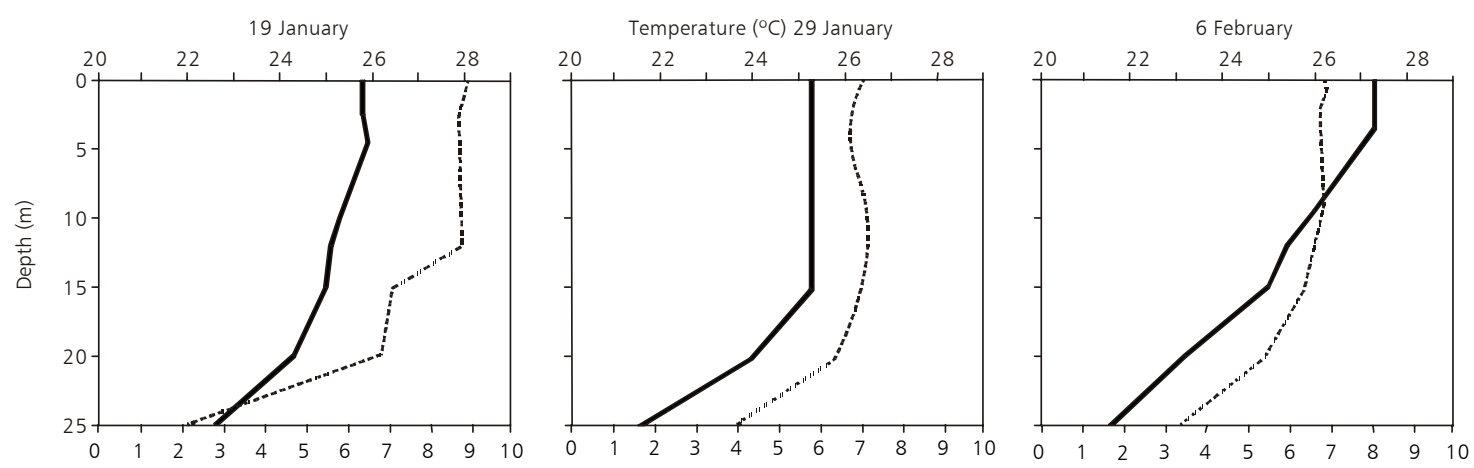

DO

Temperature $\left({ }^{\circ} \mathrm{C}\right)$

-..-.-. Dissolved oxygen (DO, mg. $\mathrm{L}^{-1}$ )

Fig. 3 - Selected profiles of temperature and dissolved oxygen in the water column, during the dry and rainy seasons, in Jurumirim Reservoir.

TABLE 2

Results of the ANOVA in determining significant variation of environmental variables and abundance of the main species of copepods, in different depths and days, in Jurumirim Reservoir.

\begin{tabular}{|l|c|c|c|c|}
\hline \multirow{2}{*}{\multicolumn{1}{|c|}{ Variable }} & \multicolumn{2}{c|}{ Dry season } & \multicolumn{2}{c|}{ Rainy season } \\
\cline { 2 - 5 } & Days & Depths & Days & Depths \\
\hline Water temperature & $\mathrm{F}=13.40^{* *}$ & $\mathrm{~F}=2.23 \mathrm{~ns}$ & $\mathrm{~F}=3.63^{* *}$ & $\mathrm{~F}=95.66^{* *}$ \\
\hline Dissolved oxygen & $\mathrm{F}=8.39^{* *}$ & $\mathrm{~F}=0.52 \mathrm{~ns}$ & $\mathrm{~F}=5.76^{* *}$ & $\mathrm{~F}=116.79^{* *}$ \\
\hline Conductivity & $\mathrm{F}=31.31^{* *}$ & $\mathrm{~F}=2.12 \mathrm{~ns}$ & $\mathrm{~F}=63.83^{* *}$ & $\mathrm{~F}=18.03^{* *}$ \\
\hline $\mathrm{pH}$ & $\mathrm{F}=11.38^{* *}$ & $\mathrm{~F}=0.56 \mathrm{~ns}$ & $\mathrm{~F}=6.30^{* *}$ & $\mathrm{~F}=7.30^{* *}$ \\
\hline Suspended matter & $\mathrm{F}=0.97 \mathrm{~ns}$ & $\mathrm{~F}=0.97 \mathrm{~ns}$ & $\mathrm{~F}=3.40^{* *}$ & $\mathrm{~F}=1.07 \mathrm{~ns}$ \\
\hline Chlorophyll-a & $\mathrm{F}=6.43^{* *}$ & $\mathrm{~F}=1.17 \mathrm{~ns}$ & $\mathrm{~F}=18.28^{* *}$ & $\mathrm{~F}=2.93^{*}$ \\
\hline$N$. iheringi & $\mathrm{F}=7.10^{* *}$ & $\mathrm{~F}=2.12 \mathrm{~ns}$ & $\mathrm{~F}=7.44^{* *}$ & $\mathrm{~F}=16.28^{* *}$ \\
\hline$T$. minutus & $\mathrm{F}=4.85^{* *}$ & $\mathrm{~F}=3.13^{*}$ & $\mathrm{~F}=1.40 \mathrm{~ns}$ & $\mathrm{~F}=1.93 \mathrm{~ns}$ \\
\hline
\end{tabular}

** Significant at $1 \% ; *$ significant at $5 \%$; and ns non-significant. 

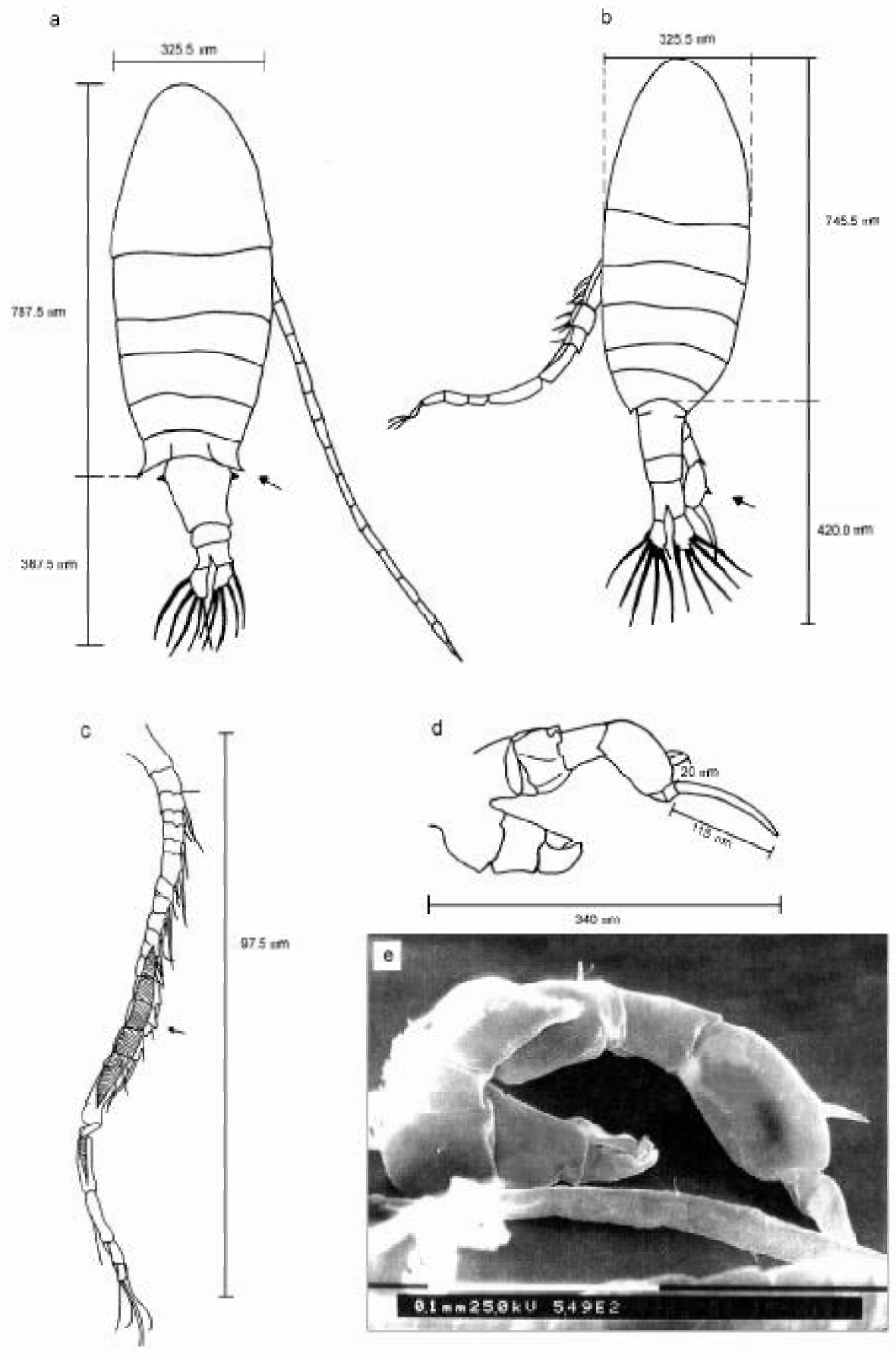

Fig. 4 - Notodiaptomus iheringi: (a) female (dorsal view, x 100); (b) male (dorsal view, x 100); (c) right antennule of male (x 200); (d) $5^{\text {th }}$ leg of male (x 200); (e) $5^{\text {th }}$ leg of male (x 655). 

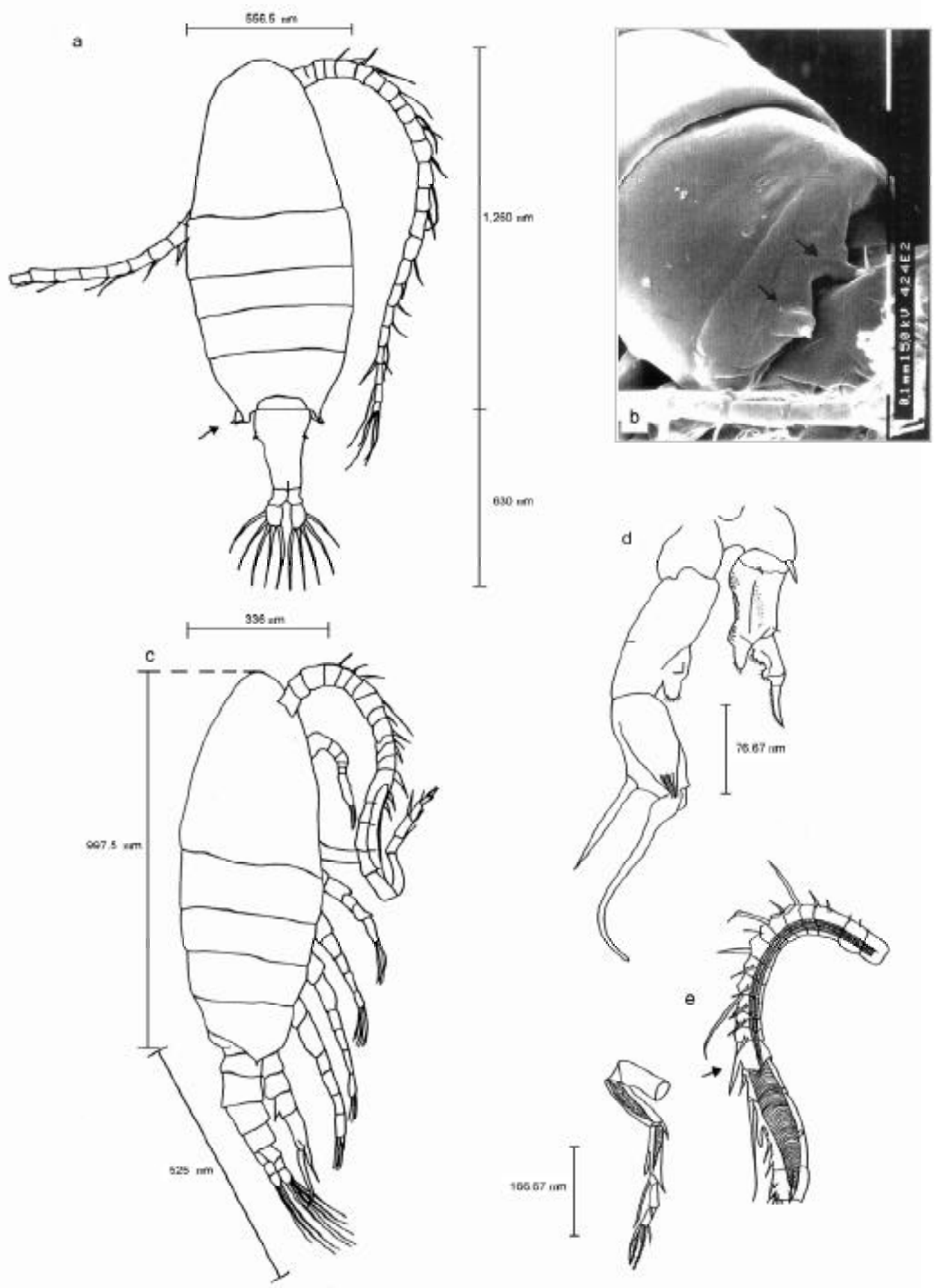

Fig. 5 - Argyrodiaptomus furcatus: (a) female (dorsal view, x 100); (b) detail of last thoracic segment of female (x 500); (c) male (lateral view, x 100); (d) $5^{\text {th }}$ leg of male (x 400); (e) right antennule of male (x 400). 


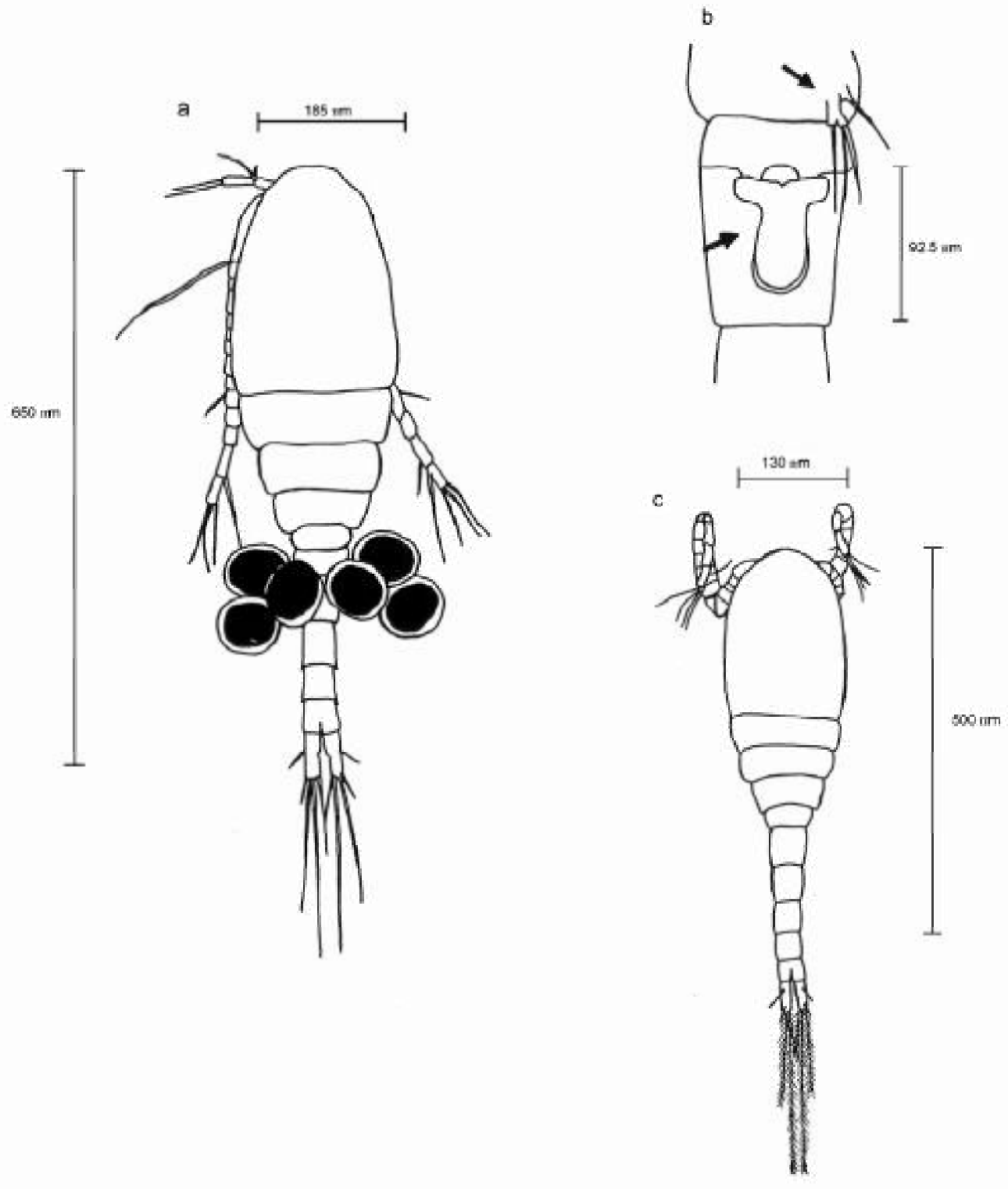

Fig. 6 - Thermocyclops minutus: (a) female (dorsal view, $\mathrm{x} 200$ ); (b) urosome (ventral), $5^{\text {th }}$ leg and seminal receptacle (x 400); (c) male (dorsal view, x 200).

However, a greater variation was observed during the dry season, when there was lower density at the beginning of the sampling period and an increase in the number of organisms in the second half of the period. During the rainy season a peak of abundance occurred in 25 January. In the other days relatively lower values were found with some moderate variation (Fig. 10).

During the dry period, Cyclopoida was more abundant than Calanoida and from 3 to 9 July constituted more than $90 \%$ of the copepods. During the rainy season, it a large increase of Calanoida was 
observed and also some alternation in the proportion of abundance between the orders (Fig. 11). Figs. 12 and 13 show the relationships among the development phases of Calanoida and Cyclopoida, respectively. Proportions among nauplii, copepodid and adult were more stable for the cyclopoids, mainly in the rainy season, when the nauplii had a relative abundance larger than $80 \%$, during the whole sampling period. Larger proportion of copepodids and adults of cyclopoids was noted during the dry season. Nauplii of calanoids were proportionally more abundant during the dry season.

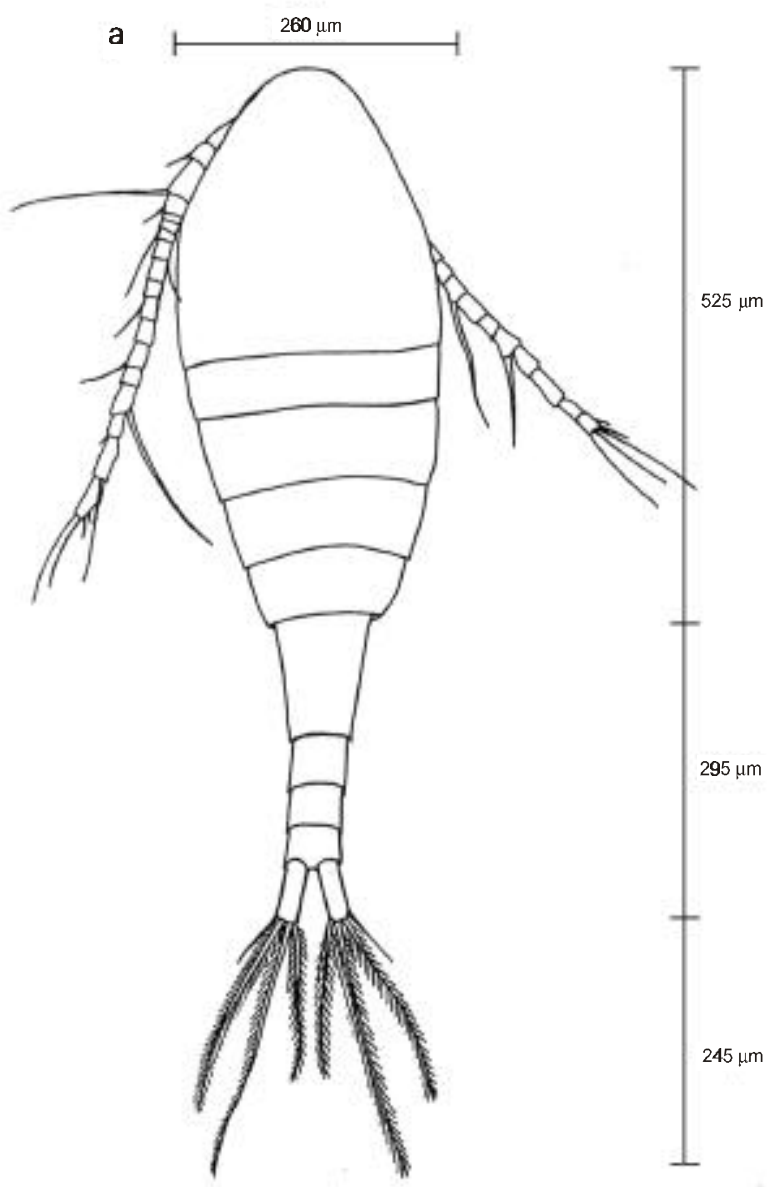

b
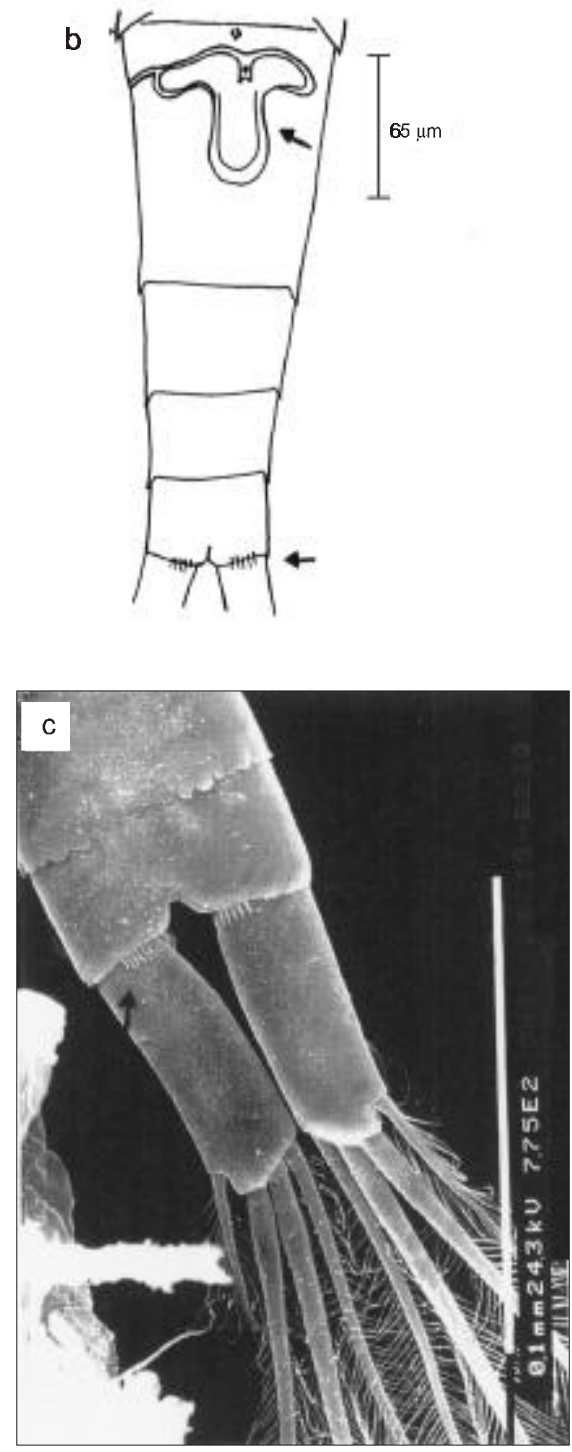

Fig. 7 - Thermocyclops decipiens: (a) female (dorsal view, $x$ 200); (b) urosome (ventral) and seminal receptacle (X 400); (c) caudal rami, detail of last abdominal segment (x 594). 

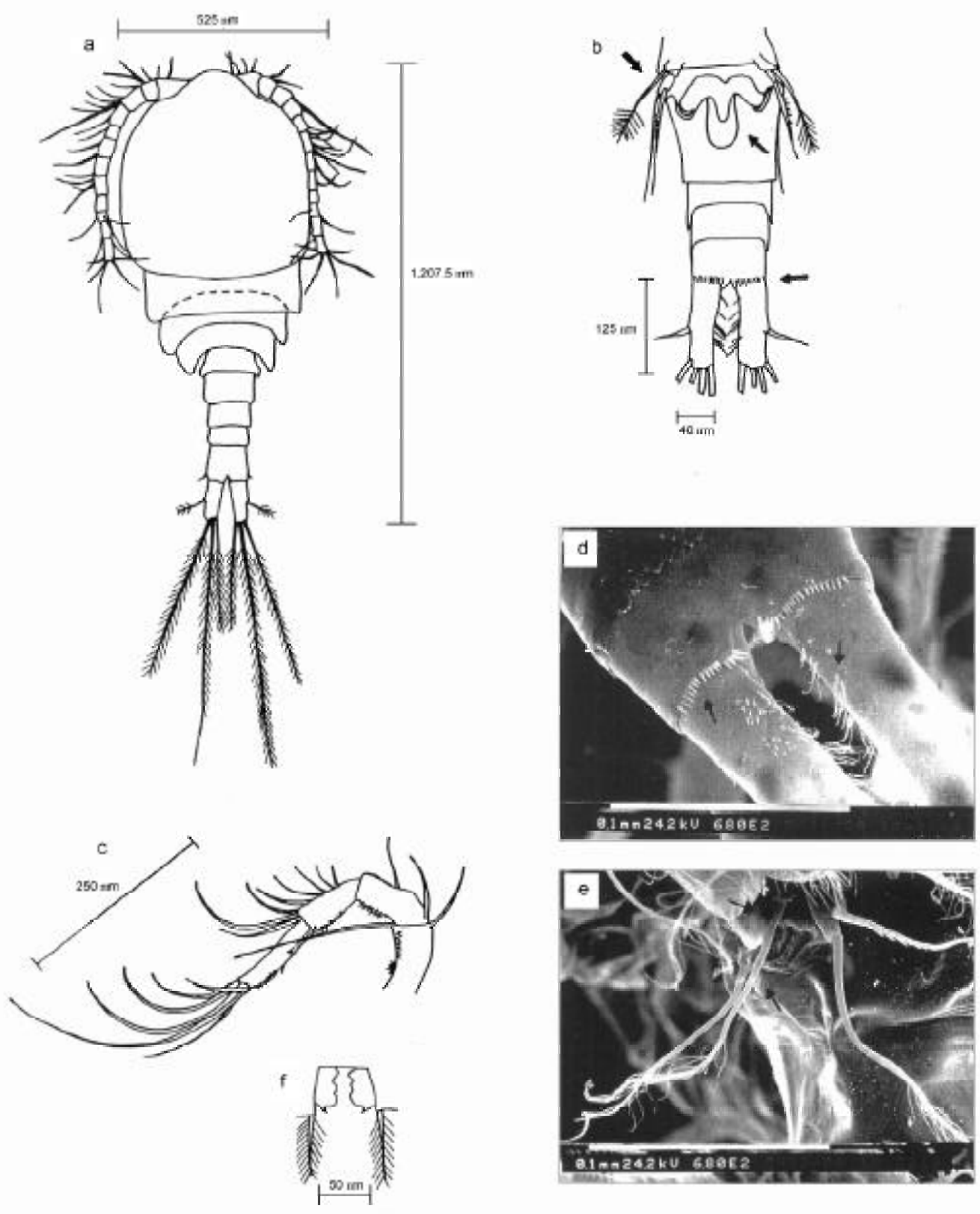

Fig. 8 - Mesocyclops longisetus: (a) female (dorsal view, x 200); (b) urosome (ventral), $5^{\text {th }}$ leg, seminal receptacle and caudal rami (x 200); (c) antennae (x 200); (d) detail of last abdominal segment and caudal rami (x 815); (e) detail $5^{\text {th }}$ leg (x 815).

In the rainy season the copepodids of calanoids showed larger abundance. The species of Copepoda found in this study are the calanoids Argyrodiaptomus furcatus (Sars) and Notodiaptomus iheringi (Wright), and the cyclopoids Meso- cyclops longisetus (Thiébaud), Thermocyclops decipiens (Fischer), and T. minutus (Lowndes) (Figs. 4 to 8). Variations in abundance of the species of Calanoida and Cyclopoida for both seasons are shown in Figs. 14 and 15, respectively. 
During the dry season, T. minutus dominated among Copepoda adults.

The pattern of variation in this period was similar for the three species of Cyclopoida, M. longisetus, T. decipiens, and T. minutus. There was also a certain similarity in patterns for $A$. furcatus and $N$. iheringi. The Calanoida variation coincided with the variation pattern of all copepods, which indicates that this suborder had an important influence in fluctuation of the group as a whole.

The variance analysis detected significant differences in abundance variation for T. minutus and $N$. iheringi. In relation to vertical distribution, only T. minutus showed significant variation between depths (Table 2).

During the rainy season, $N$. iheringi was dominant among the adults of Copepoda. T. decipiens and T. minutus showed similar variations in abundance. On some days, the numerical increase of the species of Thermocyclops coincided with a decrease in the density of M. longisetus. The density of $N$. iheringi varied significantly with days and depths, but T. minutus did not.

As to the proportion between male and female, $N$. iheringi showed similar values for both sexes in the two seasons studied (Fig. 16).
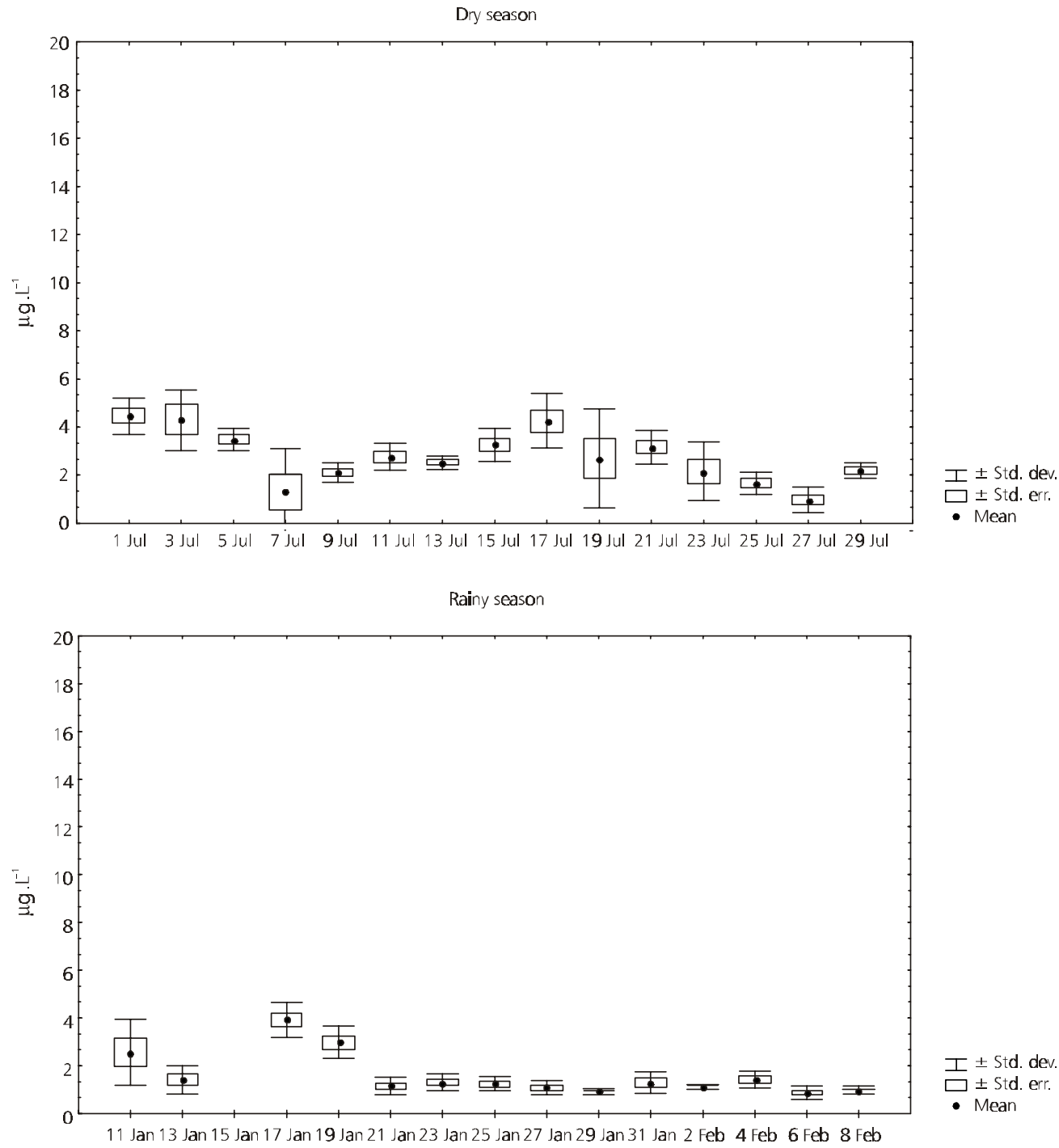

Fig. 9 - Mean, standard deviation, and standard error for chlorophyll-a, in the water column of Jurumirim Reservoir. 

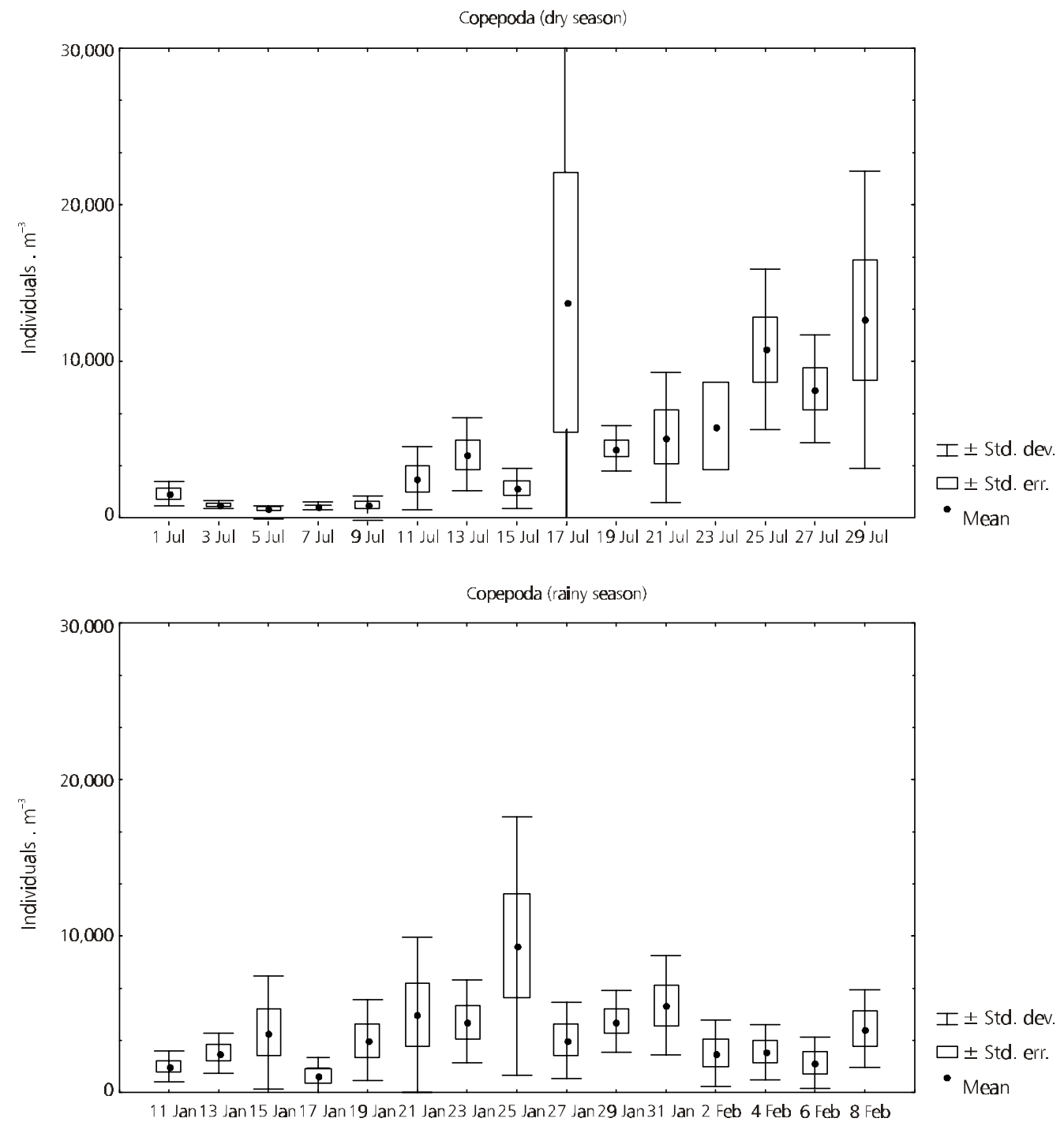

Fig. 10 - Mean, standard deviation, and standard error for copepods abundance, in the water column of Jurumirim Reservoir.

T. minutus showed higher female proportion in most sampling days, mainly in the rainy season. Male of $T$. decipiens were generally absent or in density very inferior to that found for the females (Fig. 17). In Fig. 18 presents some selected profiles on vertical distribution of the main copepods species. A larger number of organisms was found within the first $20 \mathrm{~m}$ of depth during the dry season. A higher abundance of T. minutus was found between 0 and $10 \mathrm{~m}$. During the rainy season Notodiaptomus iheringi exhibited larger densities of individuals above $15 \mathrm{~m}$. At that time, the species of Thermocyclops were generally more abundant between 10 and $25 \mathrm{~m}$ (Fig. 18).
Analysis of correlation between the species and the environmental variables

Water temperature showed higher correlation with density of the species of Calanoida, especially with $N$. iheringi during the dry season (Table 3).

Some correlation between densities of zooplankton and phytoplankton was especially evident in the dry season, when A. furcatus was positively correlated with Cryptophyceae, and most Calanoida showed negative correlation with Aulacoseira spp., Cyclotella stilligera, and Monoraphydium minutum. 

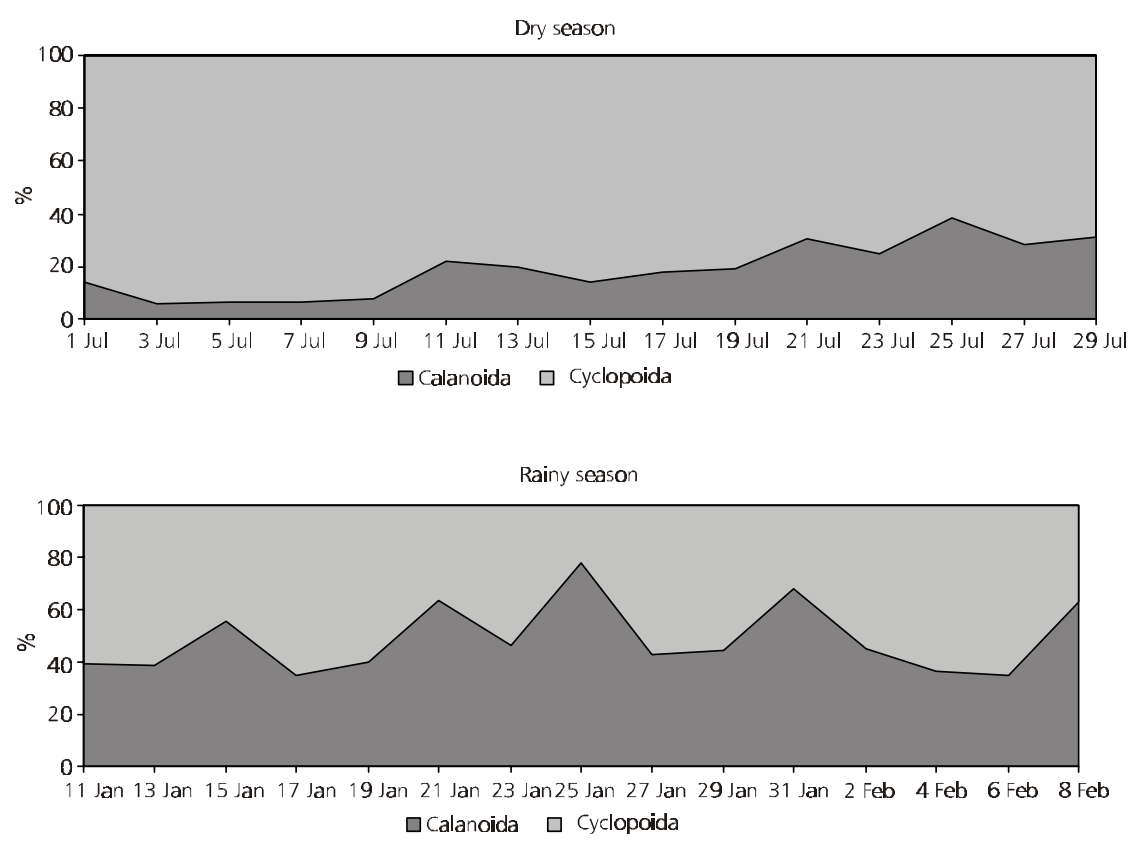

Fig. 11 - Calanoida and Cyclopoida proportions (\%) in Jurumirim Reservoir.
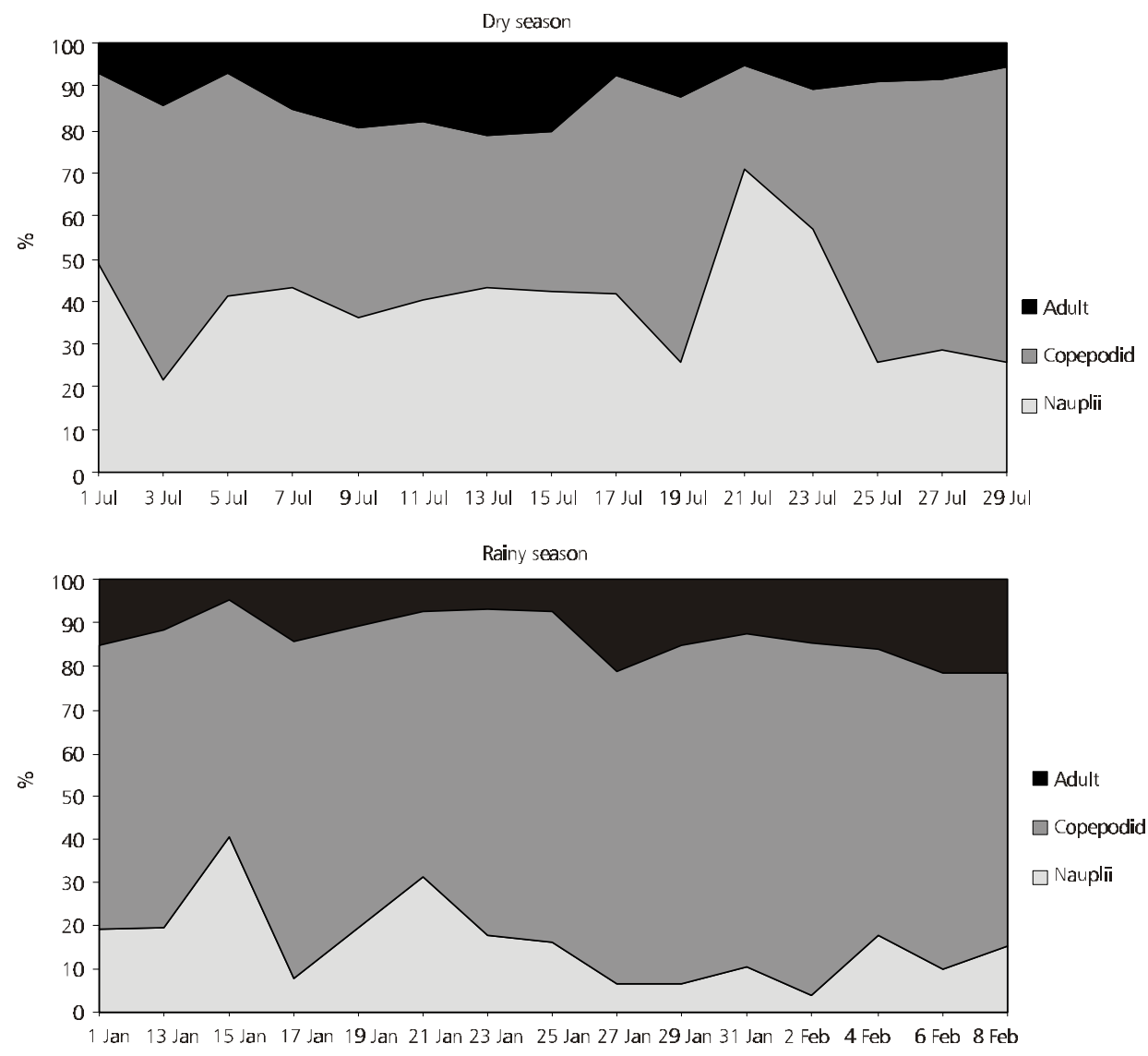

Fig. 12 - Nauplii, copepodid, and adult proportions of calanoid in the water column of Jurumirim Reservoir. 

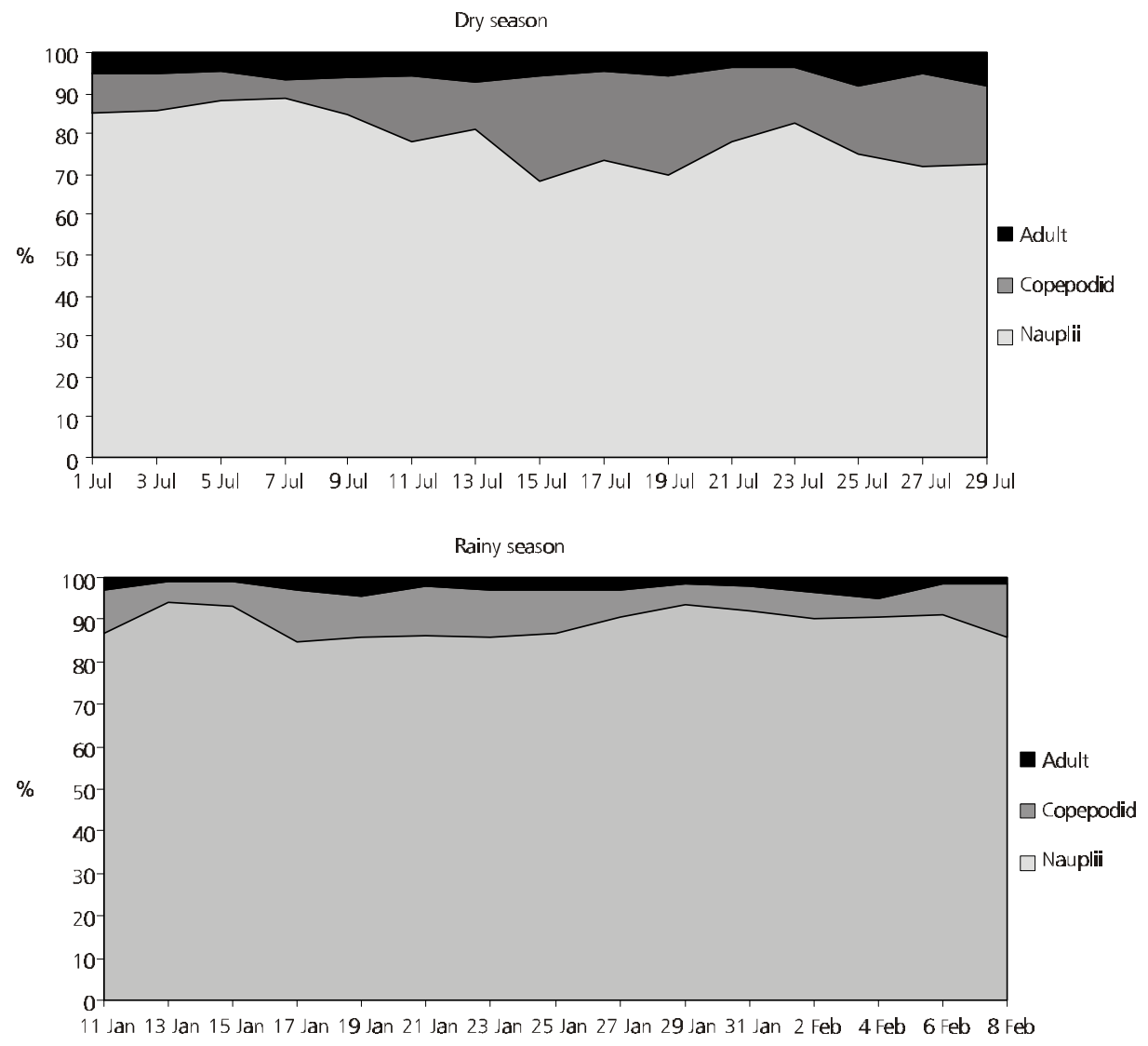

Fig. 13 - Nauplii, copepodid, and adult proportions of cyclopoid, in the water column of Jurumirim Reservoir.

During the rainy season, for only $N$. iheringi was there a positive correlation with Microcystis aeruginosa and Chroomonas acuta, while M. longisetus showed a negative correlation with Monoraphydium minutum (Table 3 ).

\section{DISCUSSION}

During both dry and rainy periods the zooplankton community in Jurumirim Reservoir was dominated numerically by rotifers (Panarelli, 1999). Copepoda was the second group in abundance, and constituted, on the average, $26 \%$ of total zooplankton.

However, if the same results were expressed in units of biomass, probably the importance of the copepods in the community structure would be even more prominent. Numerical dominance in the zooplankton community by rotifers was also found in another oligotrophic reservoir, Broa Reservoir, in the State of São Paulo (MatsumuraTundisi et al., 1989). Rotifers constituted $65.5 \%$ of total zooplankton, followed by cladocerans
(17.2\%) and copepods (16.9\%). However, when these values were expressed in terms of dry weight, the copepods exhibited the largest proportion of total biomass, $80.8 \%$, followed by cladocerans, $13.8 \%$ and rotifers, $<5 \%$.

Major differences were observed in population abundances and dominance between dry and rainy periods, which indicates that seasonal effects are important factors in the dynamics of these populations. The dominance of Cyclopoida, especially T. minutus during the dry season, and the numerical increase of Calanoida, mainly $N$. iheringi in the rainy season, were probably related to temperature variation and the phytoplankton community structure. The species of Calanoida showed a significant correlation with water temperature.

Espíndola (1994) verified experimentally, that the development of $N$. iheringi from egg to phase nauplius I decreased with temperature increase, from 4.3 days at $18^{\circ} \mathrm{C}$ to 1.1 days at $28^{\circ} \mathrm{C}$. The development time from egg to egg significantly decreased as well, from 17.6 days at $23^{\circ} \mathrm{C}$ to 9.7 days at $28^{\circ} \mathrm{C}$. At a lower temperature $\left(18^{\circ} \mathrm{C}\right)$ there 
was an increase in mortality rate and a decrease in reproductive efficiency for these species. These data show that a considerable increase in number of copepods can occur due to fast development in high temperature conditions. On the other hand, Rietzler (1995) observed in experiments with $T$. minutus a decrease in longevity with temperature increase, from 37 days at $18^{\circ} \mathrm{C}$ to 7.7 days at $28^{\circ} \mathrm{C}$.

The results of the experiments mentioned above show that $N$. iheringi and T. minutus seem to have better physiologic performance (longevity and development time) in different temperature ranges. This fact contributes to understanding the pattern of variation in calanoid and cyclopoid abundance observed in the present study, with higher density of calanoids during the rainy season (with temperature near $24.6^{\circ} \mathrm{C}$ ) and higher density of cyclopoids in the dry season (temperature near $19.8^{\circ} \mathrm{C}$ ).

Higher proportions of copepodids and adult calanoids observed during the rainy season can be associated with greater longevity in high temperature conditions. The same can be inferred for cyclopoids in lower temperature conditions. The higher density of nauplii in possibly adverse conditions (cyclopoid in warmer and calanoid in cooler periods) can be a strategy of these populations for remaing in the environment with the generation of great numbers of descendents, even so a small only a small part of these reach the adult phase. Nogueira (1996), Nogueira \& Panarelli (1997), and Mitsuka (1998) verified the same variation pattern in the ratio of Calanoida/Cyclopoida abundance when compared to the dry (winter) and rainy (summer) seasons in Jurumirim Reservoir. The male/female relation was more stable for $N$. iheringi in both seasons, with similar values for male and female density. The male/ female ratio was stable for T. minutus during the dry season, but a high was observed in the rainy season, when this species was less abundant. Males of $T$. decipiens appeared only sporadically.

Dry season

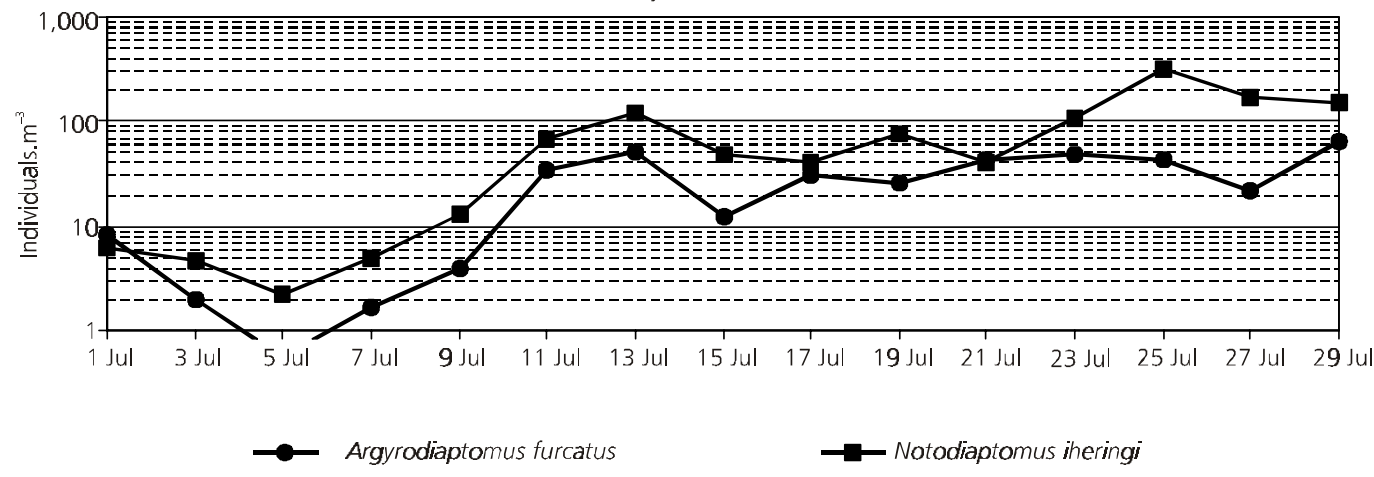

Rainy season

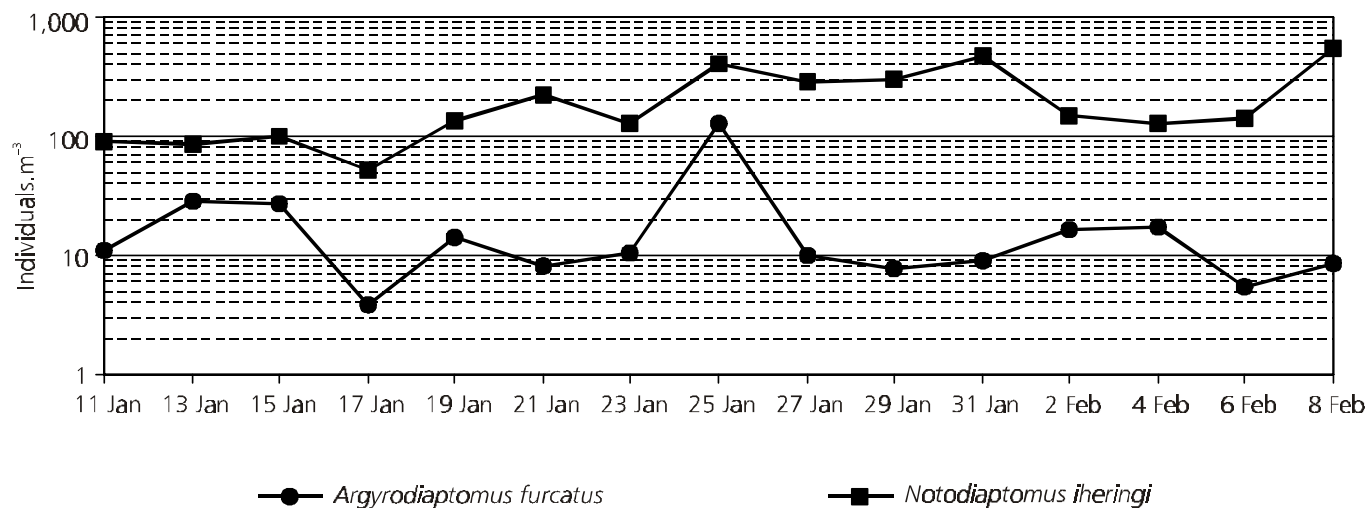

Fig. 14 - Mean density of organisms for the species of Calanoida, in the water column of Jurumirim Reservoir. 


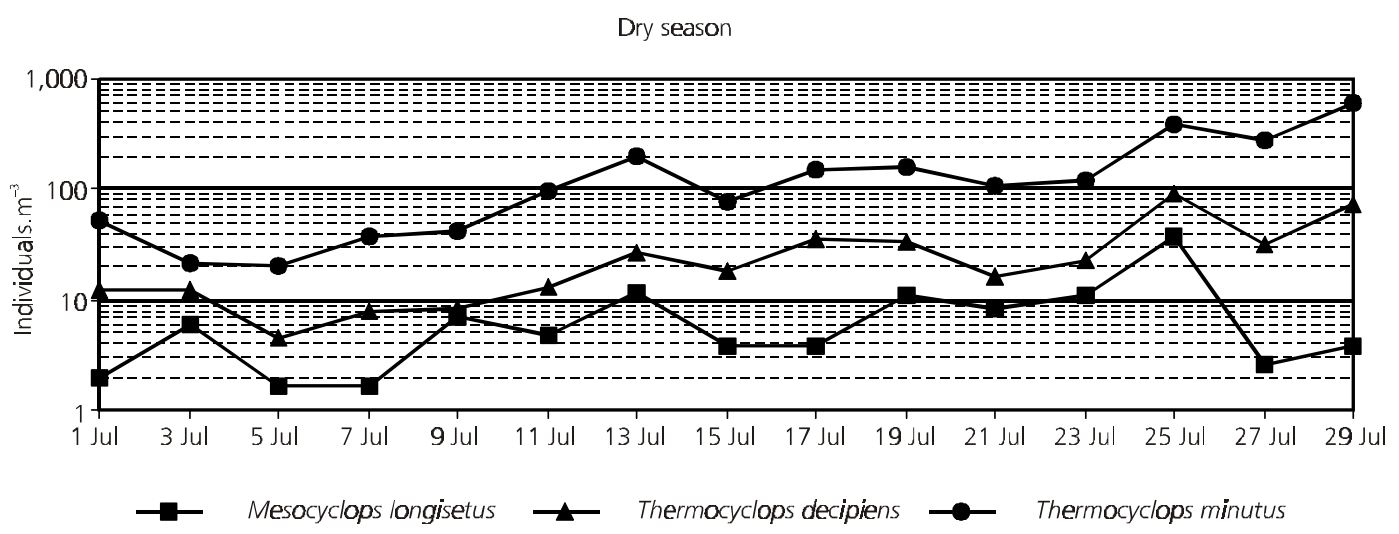

Rainy season

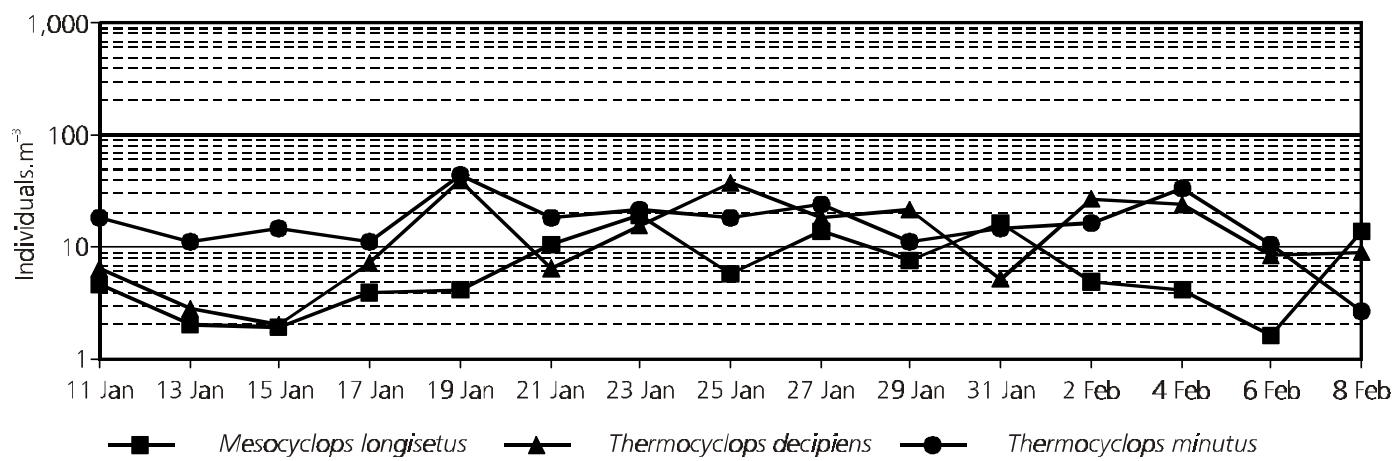

Fig. 15 - Mean density of organisms for species of Cyclopoida in the water column of Jurumirim Reservoir.
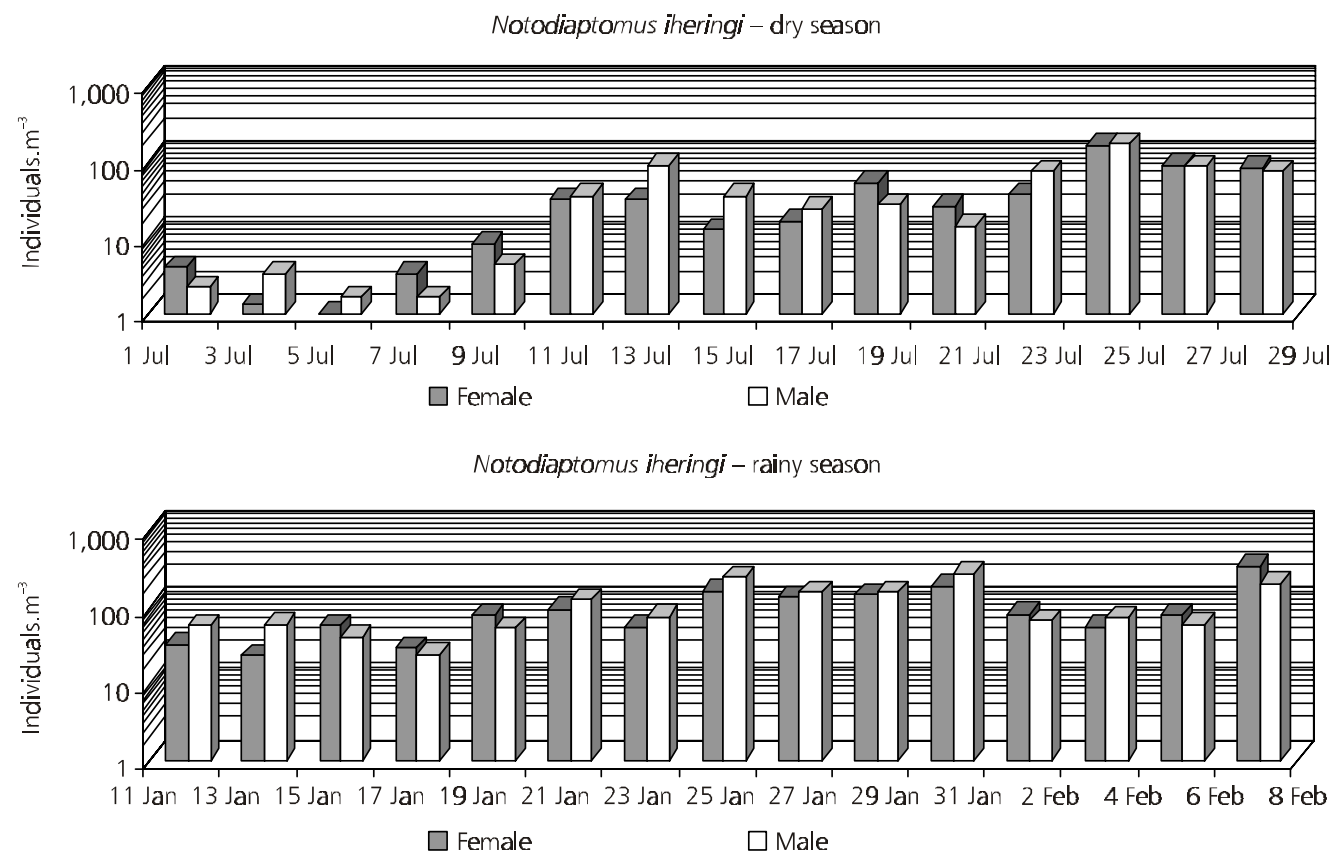

Fig. 16 - Male/female relation for species of calanoid in Jurumirim Reservoir. 

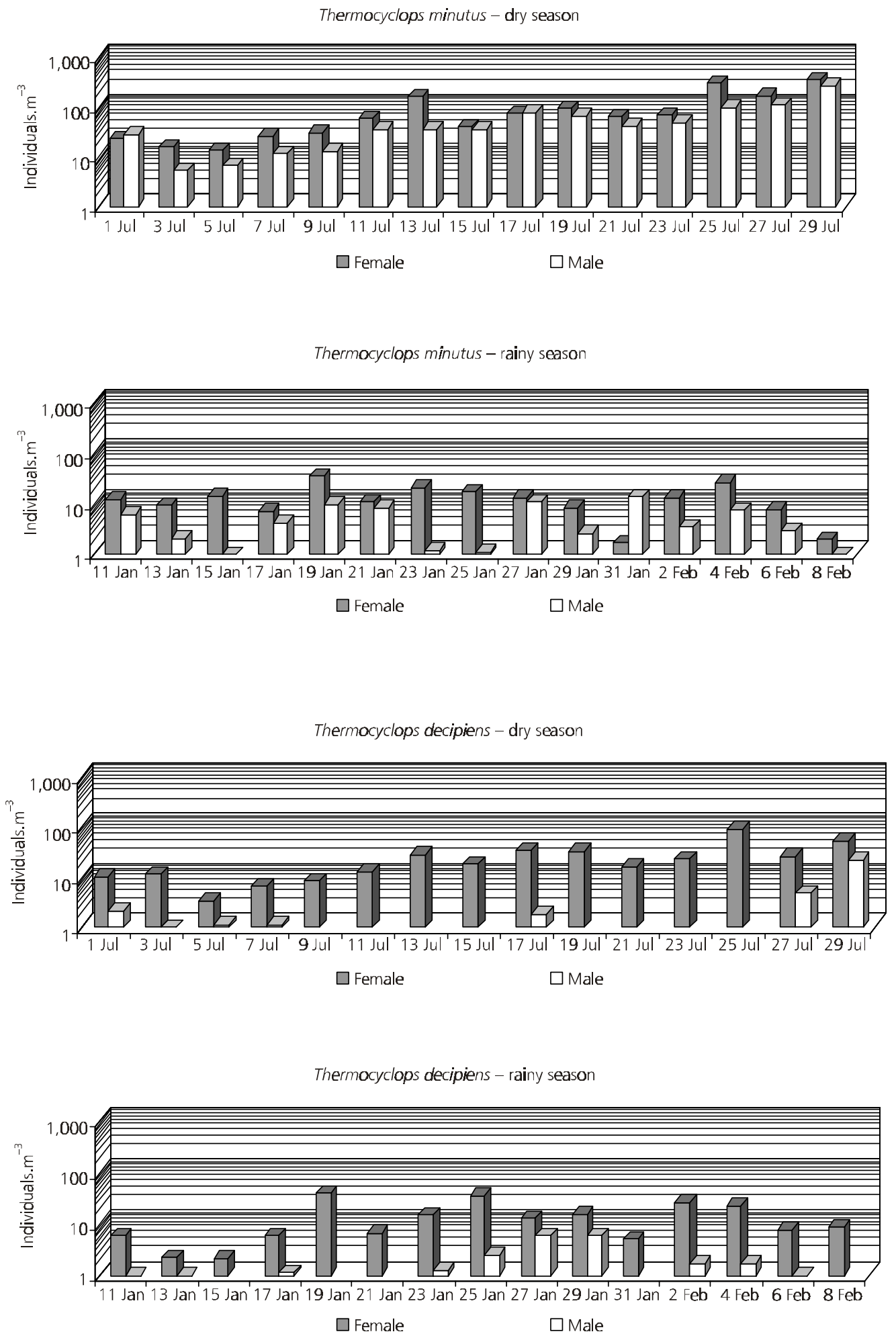

Fig. 17 - Male/female relation for species of cyclopoid in Jurumirim Reservoir. 

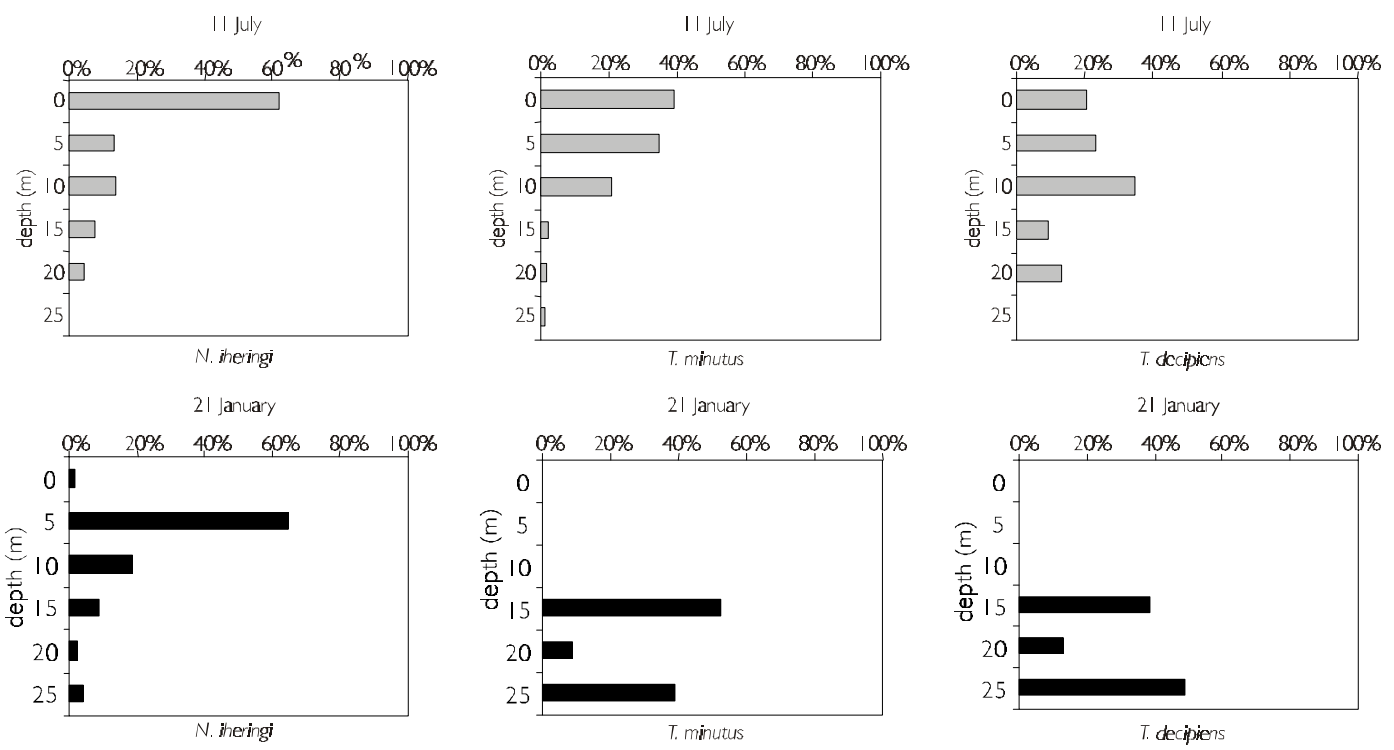

Fig. 18 - Selected profiles on the vertical distributions (\% of abundance) for Nodiaptomus iheringi, Thermocyclops minutus and Thermocyclops decipiens.

TABLE 3

Correlation coefficients (Pearson) between densities of Copepoda species and phytoplankton species as well as copepod species and temperature during the dry and rainy season in Jurumirim Reservoir.

\begin{tabular}{|c|c|c|c|c|c|c|c|c|c|}
\hline \multicolumn{10}{|c|}{ Dry season } \\
\hline & $\begin{array}{l}\text { Tempe- } \\
\text { rature }\end{array}$ & $\begin{array}{c}\text { Microcys- } \\
\text { tis } \\
\text { aeruginosa }\end{array}$ & $\begin{array}{c}\text { Aulaco- } \\
\text { seira } \\
\text { granulata }\end{array}$ & $\begin{array}{c}\text { Crypto- } \\
\text { monas } \\
\text { marsonii }\end{array}$ & $\begin{array}{l}\text { Aulaco- } \\
\text { seira } \\
\text { ambigua }\end{array}$ & $\begin{array}{c}\text { Chroomo- } \\
\text { nas } \\
\text { acuta }\end{array}$ & $\left|\begin{array}{c}\text { Cyclo- } \\
\text { tella } \\
\text { stelligera }\end{array}\right|$ & $\begin{array}{l}\text { Aulaco- } \\
\text { seira } \\
\text { distans }\end{array}$ & $\begin{array}{l}\text { Monora- } \\
\text { phydium } \\
\text { minutum }\end{array}$ \\
\hline Copepoda & $0.3145^{*}$ & -0.0031 & -0.4281 & 0.4599 & -0.3145 & 0.4584 & $-0.6527 * \mid$ & $-0.6461^{*}$ & $-0.6670^{*}$ \\
\hline A. furcatus & $0.3261 *$ & 0.3112 & $-0.5557^{*}$ & $0.6881^{*}$ & $-0.5466^{*}$ & $0.5834^{*}$ & -0.3525 & $-0.7983 *$ & $-0.5241^{*}$ \\
\hline N. ihering $i$ & $0.5233^{*}$ & 0.0601 & $-0.7464 *$ & 0.3960 & $-0.6862 *$ & 0.3932 & -0.3505 & $-0.6945^{*}$ & $-0.6099 *$ \\
\hline $\begin{array}{l}\text { M. } \\
\text { longisetus }\end{array}$ & $0.4713^{*}$ & -0.2068 & $-0.7031^{*}$ & 0.2137 & $-0.5608^{*}$ & 0.1359 & -0.0860 & -0.4933 & -0.3082 \\
\hline $\begin{array}{l}T . \\
\text { decipiens }\end{array}$ & 0.2339 & 0.0068 & $-0.5407^{*}$ & 0.3291 & -0.4324 & 0.3724 & -0.5014 & $-0.5613^{*}$ & $-0.5819^{*}$ \\
\hline T. minutus & 0.2114 & 0.2381 & -0.3911 & 0.3682 & -0.4028 & 0.4681 & $-0.5341 *$ & $-0.5311^{*}$ & $-0.5728^{*}$ \\
\hline \multicolumn{10}{|c|}{ Rainy season } \\
\hline & $\begin{array}{l}\text { Tempe- } \\
\text { rature }\end{array}$ & $\begin{array}{c}\text { Microcys- } \\
\text { tis } \\
\text { aeruginosa }\end{array}$ & $\begin{array}{c}\text { Chroom } \\
\text { o-nas } \\
\text { acuta }\end{array}$ & $\begin{array}{c}\text { Cyclo- } \\
\text { tella } \\
\text { stelligera }\end{array}$ & $\begin{array}{l}\text { Aulaco- } \\
\text { seira } \\
\text { distans }\end{array}$ & $\begin{array}{c}\text { Crypto- } \\
\text { monas } \\
\text { marsonii }\end{array}$ & $\begin{array}{c}\text { Chlorella } \\
\text { vulgaris }\end{array}$ & $\begin{array}{l}\text { Monora- } \\
\text { phydium } \\
\text { minutum }\end{array}$ & $\begin{array}{c}\text { Aulaco- } \\
\text { seira } \\
\text { granulata }\end{array}$ \\
\hline Copepoda & $0.5008^{*}$ & 0.3111 & 0.1100 & -0.2619 & 0.1268 & 0.1442 & -0.2581 & -0.3972 & 0.2018 \\
\hline A. furcatus & $0.2686^{*}$ & 0.1013 & -0.1131 & -0.0045 & 0.0502 & -0.0803 & 0.0188 & -0.1714 & 0.0150 \\
\hline$N$. ihering $i$ & $0.3318^{*}$ & $0.6105^{*}$ & $0.5625^{*}$ & -0.4896 & -0.2624 & 0.3694 & -0.3079 & -0.5177 & 0.4732 \\
\hline $\begin{array}{l}\text { M. } \\
\text { longisetus }\end{array}$ & -0.1983 & 0.2636 & 0.2425 & -0.5180 & 0.0997 & 0.1203 & -0.1925 & $-0.5724^{*}$ & 0.3103 \\
\hline $\begin{array}{l}T . \\
\text { decipiens }\end{array}$ & -0.0740 & 0.3443 & 0.1166 & -0.4133 & 0.2017 & 0.4402 & -0.2578 & 0.1199 & 0.1819 \\
\hline T. minutus & -0.0928 & -0.1416 & -0.2882 & -0.0476 & 0.3879 & 0.1574 & -0.0458 & 0.4872 & -0.1477 \\
\hline
\end{tabular}

* Significant values of correlation between zooplankton and phytoplankton $(\mathrm{n}=15 ; \mathrm{r}>0.52 ; \mathrm{p}<0.05)$; between temperature and zooplankton $(\mathrm{n}=90 ; \mathrm{r}>0.25 ; \mathrm{p}<0.05)$. 
In the dry season there was a tendency towards spatial segregation between $N$. iheringi, which generally occupied superficial layers (between 0 and $5 \mathrm{~m}$ ), and the two species of Thermocyclops, which were more abundant below $5 \mathrm{~m}$.

Probably the species of Cyclopoida are distributed preferentially in layers where temperature values are lower, whereas during the period of isothermal conditions these species showed higher abundances between 0 and $10 \mathrm{~m}$ depth. The presence of the species of Thermocyclops in deeper layers during the thermal stratification period, also indicates that they can tolerate lower concentrations of dissolved oxygen, which are observed in the region near the hypolimnion. In a study on vertical migration of zooplankton in Jurumirim Reservoir, Nogueira \& Panarelli (1997) verified preferential distribution of T. minutus in the hypolimnion, especially during the day and in stratified conditions.

Ferguson et al. (1982) considered temperature and food resources as the main factors responsible for changes in population densities and in the age structure of zooplankton communities. The chlorophyll-a values did not show significant correlation with the zooplanktonic population, however when analyzed the phytoplanktonic groups showed correlations mainly in the dry season. For copepods, we should consider that calanoids and cyclopoids have different feeding preferences. Calanoids are filter-feeding and cyclopoids capture alimentary particles. Esteves \& Sendacz (1988) suggested that cyclopoids can ingest portions of filamentous and colonial algae, which may be inadequate as a food resource for the calanoids. On the other hand, Fulton (1988), based on experimental results, proposed that the inhibitor effect of blue-green algae for the development of zooplankton, would be more related to toxicity than to morphology of these algae. In an experimental study on feeding processes of Argyrodiaptomus furcatus using five phytoplankton species, Tavares \& Matsumura-Tundisi (1984), verified that Scenedesmus quadricaudata was filtered at higher rates than Chlorella zoofingensis, although the latter species was present in a higher concentration. According to these authors, differences in filtration and assimilation rates for different algae may be associated with differences in nutrient content and cell morphology, palatability, and even toxicity. Rietzler \& Espíndola (1998) analyzed the gut content of copepods and verified for the cy- clopoids Mesocyclops kieferi and Thermocyclops decipiens ingestion of a high percentage of organic detritus besides consumption of colonies of Cyanophyceae (mainly Microcystis); for calanoids (Notodiaptomus) the main food items were diatoms and phytoflagellates. They concluded that colonies of Microcystis provided (directly or not) an alternative food resource for cyclopoids.

During the dry season, for the same sampling days, Ferreira (1998) found higher densities of Microcystis. The capacity of the cyclopoids to use colonies of Microcystis, or organic detritus associated with them, can explain their dominance in Jurumirim Reservoir in this period. Species of Cryptophyceae, known as an edible food resource for zooplankton (Klaveness, 1988), were positively correlated with A. furcatus during the same season. Significant correlations between zooplankton and phytoplankton populations were not detected during the rainy season, despite presence of the same species. Therefore, abiotic factors may play a determinantal role in the dynamics of plankton communities in Jurumirim Reservoir during certain periods of the year.

Short-term variations in abundance of calanoids were observed in both periods of the year. However, for cyclopoids, conspicuous daily variations occurred only in the dry season, when outflow was higher (Table 1). Zooplankton opulations can exhibit aggregate patterns of distribution, in patches with a large number of organisms. The advective currents as much as the action of the wind can promote displacement of these aggregates of individuals. In spite of unverified direct relation between wind speed and abundance variations, it is important to notice that daily oscillations in the wind speed occurred and that these induce movements of water masses. In the present study, the main cause of density variations of populations during short time intervals was probably the transportation of organisms due to water mass movements, as indicated by great changes observed in density. For instance, the fivefold increase in abundance of $N$. iheringi, between 7 and 9 July, when water temperature was relatively low $\left(19.5^{\circ} \mathrm{C}\right)$, seems incompatible with natural changes in the dynamics of a single population. According to Espíndola (1994), in these temperature conditions, increases in mortality and development time rates for this species would be expected. 
In reservoirs with continuous water flow, displacement of water masses certainly contribute to variability in population abundances. Nogueira \& Panarelli (1997) in studying zooplankton vertical distribution at the dam region of Jurumirim Reservoir, also related a great increase in density with displacement of adjacent water masses. They verified an increase of more than $100 \%$ in abundance of total zooplankton within an 8-hour interval. According to Lewis Jr. (1978), some sophisticated information is available on zooplankton patch structure at given instants in time, but knowledge about the behavior of patch structure in temporal scales is still not sufficient for better understanding the relationship between temporal and spatial variation of planktonic populations. The movements of patches of zooplankton can have an important role in community dynamics. The same site can be exploited by a large number of individuals at different times, and the same set of organisms can exploit several parts of the ecosystem during short periods of time.

Some abiotic variables, such as temperature, dissolved oxygen and $\mathrm{pH}$, as well as abundance of taxa of phytoplankton (Ferreira, 1998), showed significant variations between days for the same sampling period. This environmental variability seems to have influenced organism distribution or even fluctuation in abundance of copepod populations, promoting either organism increase or decrease in distinct intervals of time.

Our data showed that variations in abundance of copepod populations, within a relatively short interval of time, can be as great as, or even greater than, fluctuations observed in seasonal series. This reinforces results obtained by Twombly (1983) and Pinto-Coelho (1987), who have emphasized the importance of short-term fluctuations in zooplankton community dynamics.

Our results also indicate that future investigations, in order to contribute to better understanding of zooplankton community ecology in Jurumirim Reservoir, should include some experimental work on particular biological and ecological responses of the main zooplankton species to a range of variations in some determinantal environmental variables.
Acknowledgments - We thank Fapesp (process 91/0612-5 thematic project and 96/3435-0 - scholarship to the first author) for financial support. We also thank Dr. Antônio C. S. Pião for the statistical analysis, Hamilton A. Rodrigues for field work and laboratory assistance, and Nivalde A. Basso for assistance in scanning microscopy.

\section{REFERENCES}

COLE, G. A., 1979, Textbook of Limnology. The C.V. Mosby Company, Saint Louis, 283p.

ESPÍNDOLA, E. L. G., 1994, Dinâmica da associação congenérica das espécies de Notodiaptomus (Copepoda, Calanoida) no Reservatório de Barra Bonita, São Paulo. Ph.D. Thesis, Univ. São Paulo, 363p.

ESTEVES, F. A. \& SENDACZ, S., 1988, Relações entre biomassa do zooplâncton e o estado trófico de reservatórios do Estado de São Paulo. Acta Limnol. Brasil., 2: $587-$ 604.

FERGUSON, A. J. D., THOMPSON, J. M. \& REYNOLDS, C. S., 1982, Structure and dynamics of zooplankton communities maintained in closed systems, with special reference to the algal food supply. J. Plankton Res., 4: 523-543.

FERREIRA, R. A. R., 1998, Flutuações de curto prazo da comunidade fitoplanctônica na Represa de Jurumirim (Rio Paranapanema, São Paulo), em duas estações do ano (seca e chuvosa). MSc. Dissertation, Univ. São Paulo, 227p.

FISHER, T. R., MELACK, J. M., ROBERTSON, B., HARDY, E. R. \& ALVES, L. F., 1983, Vertical distribution of zooplankton and physic-chemical conditions during a 24-hour period in an amazon floodplain lake - Lago Calado, Brazil. Acta Amazônica, 13: 475-487.

FULTON, R. S., 1988, Grazing on filamentous algae by herbivorous zooplankton. Freshwater Biology, 20: 263-271.

GOLTERMAN, H. L., CLYMO, R. S. \& OHNSTAD, M. A., 1978, Methods for Physical \& Chemical Analysis of Fresh Waters. IBP Handbook 8. Blackwell Scientific Publication, Oxford, 213p.

HENRY, R., 1990, Amônia ou fosfato como agente estimulador do crescimento do fitoplâncton na Represa de Jurumirim (Rio Paranapanema, SP). Rev. Brasil. Biol., 50(4): 883-892.

HENRY, R., 1992, The oxygen deficit in Jurumirim Reservoir (Paranapanema River, São Paulo, Brazil). Jpn. J. Limnol., 53(4): 379-384.

HENRY, R., 1993a, Thermal regime and stability of Jurumirim Reservoir (Paranapamena River, São Paulo, Brazil). Int. Rev. Ges. Hydrobiol., 78: 501-511.

HENRY, R., 1993b, Primary production by phytoplankton and its controlling factors in Jurumirim Reservoir (São Paulo, Brazil). Rev. Brasil. Biol., 53(3): 489-499. 
HENRY, R. \& GOUVEIA, L., 1993, Os fluxos de nutrientes e seston em cursos de água do Alto do Paranapanema (São Paulo) - sua relação com usos do solo e morfologia das bacias de drenagem. An. Acad. Bras. Ci., 65(4): 439-451.

HENRY, R. \& MARICATTO, F. E., 1996, Sedimentation rates of tripton in Jurumirim Reservoir (São Paulo, Brazil). Limnologica, 26(1): 15-25.

HENRY, R. \& NOGUEIRA, M. N., 1999, A Represa de Jurumirim (São Paulo): primeira síntese sobre o conhecimento limnológico. In: R. Henry (ed.), Ecologia de Reservatórios: Estrutura, Função e Aspectos Sociais. Fundibio/Fapesp, Botucatu, pp. 651-686.

INFANTE, A., 1982, Annual variations in abundance of zooplankton in Lake Valencia (Venezuela). Arch. Hydrobiol., 93:194-208.

KLAVENESS, E., 1988, Ecology of the Cryptomonadida: a first review. In: C. D. Sandgren (ed.), Growth and Reproductive Strategies of Freshwater Phytoplankton. Cambridge Univ. Press, Cambridge, pp. 105-133.

LANSAC-TÔHA, F. A., THOMAZ, S. M., LIMA, A. F., ROBERTO, M. D. C. \& GARCIA, A. P. P., 1995, Vertical distribution of some planktonic crustaceans in a 'varzea' lake (Lake Pousada das Garças) of the floodplain of High River Paraná, MS, Brazil. Int. J. Ecol. Envir. Sci., 21: 67-78.

LEWIS Jr., W. M., 1978, Comparison of temporal and spatial variation in the zooplankton of a lake by means of variance components. Ecology, 59(4): 666-671.

MATSUMURA-TUNDISI, T., 1986, Latitudinal distribution of Calanoida copepods in freshwater aquatic systems of Brazil. Rev. Brasil. Biol., 46: 527-553.

MATSUMURA-TUNDISI, T. \& OKANO, W. Y., 1983, Seasonal fluctuations of Copepod populations in Lake Dom Helvécio (Parque Florestal, Rio Doce, Minas Gerais, Brazil). Rev. Hydrobiol. Trop., 16: 35-39.

MATSUMURA-TUNDISI, T., RIETZLER, A. C. \& TUNDISI, J. G., 1989, Biomass (dry weight and carbon content) of plankton Crustacea from Broa Reservoir (São Carlos, SP, Brazil) and its fluctuation across one year. Hydrobiologia, 179: 229-236.

MITSUKA, P. M., 1998, Empobrecimento da comunidade zooplanctônica após a passagem pela barragem da Represa de Jurumirim (Rio Paranapanema, SP). MSc. Thesis, Unesp, 237p.

NILSSEN, J. P., 1984, Tropical lakes - functional ecology and future development: The need for a process-orientated approach. Hydrobiologia, 113: 231-242.

NOGUEIRA, M. G., 1996, Composição, abundância e distribuição espaço temporal das populações planctônicas e das variáveis físico-químicas na Represa de Jurumirim, Rio Paranapanema, SP. Ph.D. Thesis, Univ. São Paulo, 439p.

NOGUEIRA, M. G., HENRY, R. \& MARICATTO, F. E., 1999, Spatial and temporal heterogeneity in the Jurumirim Reservoir, São Paulo, Brazil. Lakes and Reservoirs: research and management., 4: 107-120.
NOGUEIRA, M. G. \& MATSUMURA-TUNDISI, T., 1996, Limnologia de um sistema artificial raso (Represa Monjolinho, São Carlos, SP). Dinâmica das populações planctônicas. Acta Limnol. Brasil., 8: 149-168.

NOGUEIRA, M. G. \& PANARELLI, E., 1997, Estudo da migração vertical das populações zooplanctônicas na Represa de Jurumirim (Rio Paranapanema, SP). Acta Limnol. Brasil., 9: 55-81.

PANARELLI, E., 1999, Flutuações de curto prazo das populações zooplanctônicas na Represa de Jurumirim (zona da barragem), Rio Paranapanema, SP. MSc. Dissertation, Unesp, 367p.

PINTO-COELHO, R. M., 1987, Flutuações sazonais e de curta duração na comunidade zooplanctônica do Lago Paranoá, Brasília, DF, Brasil. Rev. Brasil. Biol., 47: 17-29.

REID, J. W., 1985, Chave de identificação e lista de referências bibliográficas para as espécies continentais sulamericanas de vida livre da ordem Cyclopoida (Crustacea, Copepoda). Bolm. Zool., Univ. São Paulo, 9: 17-143.

REID, J. W., 1988, Thermocyclops decipiens (Copepoda, Cyclopoida): exemplo de confusão taxonômica. Acta. Limnol. Brasil., 2: 479-499.

REID, J. W., 1989, The distribution of species of the genus Thermocyclops (Copepoda, Cyclopoida) in the western hemisphere, with description of $T$. parvus, new species. Hydrobiologia, 175: 149-179.

RIETZLER, A. C., 1995, Alimentação, ciclo de vida e análise da coexistência de espécies de Cyclopoida na Represa de Barra Bonita, São Paulo. Ph.D. Thesis, Univ. São Paulo, 385p.

RIETZLER, A. C. \& ESPÍNDOLA, E. L. G., 1998, Microcystis as a food source for copepods in a subtropical eutrophic reservoir. Verh. Internat. Verein. Limnol., 26: 2001-2005.

ROCHA, O. \& MATSUMURA-TUNDISI, T., 1976, Atlas do Zooplâncton (Represa do Broa, São Carlos) - I Copepoda. Univ. Federal de São Carlos, Centro de Ciências e Tecnologia, 68p.

SENDACZ, S. \& KUBO, E., 1982, Copepoda (Calanoida e Cyclopoida) de reservatórios do Estado de São Paulo. $B$. Inst. Pesca, 9: 51-89.

TAVARES, L. H. S. \& MATSUMURA-TUNDISI, T., 1984, Feeding in adult females of Argyrodiaptomus furcatus (Sars, 1901), Copepoda-Calanoida, of Lobo Reservoir (Broa), São Carlos, São Paulo, Brazil. Hydrobiologia, 113: 15-23.

TOMM, I., POZZOBON, M. G. G., DALLA COSTA, M. L. S. R. \& LANSAC-TÔHA, F. A., 1992, Distribuição vertical nictemeral de crustáceos planctônicos em um braço do Reservatório de Itaipu, PR. Rev. Unimar, 14: 57-72.

TWOMBLY, S., 1983, Seasonal and short term fluctuations in zooplankton abundance in tropical Lake Malawi. Limnol. Oceanogr., 28: 1214-1224. 